\title{
Modelling contrasting responses of wetland productivity to changes in water table depth
}

\author{
R. F. Grant ${ }^{1}$, A. R. Desai ${ }^{2}$, and B. N. Sulman ${ }^{2}$ \\ ${ }^{1}$ Department of Renewable Resources, University of Alberta, Edmonton, AB, Canada \\ ${ }^{2}$ University of Wisconsin-Madison Department of Atmospheric and Oceanic Sciences, 1225 W. Dayton St, Madison, \\ WI 53706, USA
}

Correspondence to: R. F. Grant (robert.grant@ales.ualberta.ca)

Received: 15 April 2012 - Published in Biogeosciences Discuss.: 14 May 2012

Revised: 17 September 2012 - Accepted: 21 September 2012 - Published: 1 November 2012

\begin{abstract}
Responses of wetland productivity to changes in water table depth (WTD) are controlled by complex interactions among several soil and plant processes, and hence are site-specific rather than general in nature. Hydrological controls on wetland productivity were studied by representing these interactions in connected hummock and hollow sites in the ecosystem model ecosys, and by testing $\mathrm{CO}_{2}$ and energy fluxes from the model with those measured by eddy covariance (EC) during years with contrasting WTD in a shrub fen at Lost Creek, WI. Modelled interactions among coupled processes for $\mathrm{O}_{2}$ transfer, $\mathrm{O}_{2}$ uptake, $\mathrm{C}$ oxidation, $\mathrm{N}$ mineralization, $\mathrm{N}$ uptake and $\mathrm{C}$ fixation by diverse microbial, root and mycorrhizal populations enabled the model to simulate complex responses of $\mathrm{CO}_{2}$ exchange to changes in WTD that depended on the WTD at which change was occurring. At the site scale, greater WTD caused the model to simulate greater $\mathrm{CO}_{2}$ influxes and effluxes over hummocks vs. hollows, as has been found at field sites. At the landscape scale, greater WTD caused the model to simulate greater diurnal $\mathrm{CO}_{2}$ influxes and effluxes under cooler weather when water tables were shallow, but also smaller diurnal $\mathrm{CO}_{2}$ influxes and effluxes under warmer weather when water tables were deeper, as was also apparent in the EC flux measurements. At an annual time scale, these diurnal responses to WTD in the model caused lower net primary productivity (NPP) and heterotrophic respiration $\left(R_{\mathrm{h}}\right)$, but higher net ecosystem productivity $\left(\mathrm{NEP}=\mathrm{NPP}-R_{\mathrm{h}}\right)$, to be simulated in a cooler year with a shallower water table than in a warmer year with a deeper one. This difference in NEP was consistent with those estimated from gap-filled EC fluxes in years with different water tables at Lost Creek and at similar boreal fens
\end{abstract}

elsewhere. In sensitivity tests of the model, annual NEP declined with increasing WTD in a year with a shallow water table, but rose in a year with a deeper one. The model thus provided an integrated set of hypotheses for explaining site-specific and sometimes contrasting responses of wetland productivity to changes in WTD as found in different field experiments.

\section{Introduction}

The productivity of wetland ecosystems is strongly affected by changes in water table depth (WTD). However, these effects are complex and site-specific because they arise from numerous interactions among physical and biological processes that control carbon and nutrient transformations in soils. Lowering shallow water tables has been found to increase soil respiration (Flanagan and Syed, 2011; Silvola et al., 1996) through the effects of increased access to $\mathrm{O}_{2}$ on microbial activity in drained soil (Moore and Dalva, 1993). However, lowering deeper water tables has been found not to affect, or even to reduce, soil respiration (Lafleur et al., 2005; Muhr et al., 2011; Scanlon and Moore, 2000) because effects on microbial activity from increased uptake of $\mathrm{O}_{2}$ in deeper drained soil may be offset by those from reduced access to substrates in dry surface soil (Dimitrov et al., 2010a).

The relationship between WTD and soil respiration therefore depends on the hydrological and biological properties of wetland soils. Those with large water holding capacity and low macroporosity drain more slowly, and so maintain soil wetness through capillary rise, enabling soil respiration to 
increase as water tables deepen. Soils with low water holding capacity and large macroporosity drain more rapidly, and so are less able to maintain surface wetness through capillary rise, causing soil respiration not to increase, or even to decrease, as water tables deepen. The extent to which respiration increases in soils drained by deepening water tables also depends upon the lability vs. recalcitrance (Muhr et al., 2011; Nadelhoffer et al., 1991) and on the temperature (Blodau et al., 2007) of the deeper drained soil organic carbon (SOC).

More rapid soil respiration with greater WTD can hasten nutrient mineralization and uptake, and thereby increase primary productivity. Wood and foliar growth are more rapid on soils with lower water tables because nutrient mineralization and consequently nutrient uptake are more rapid, as evidenced by higher foliar nutrient concentrations and $\mathrm{CO}_{2}$ assimilation rates measured in spruce on drained vs. undrained peatlands (Macdonald and Lieffers, 1990) or in a treed fen over declining water tables (Flanagan and Syed, 2011). Lowering of water tables has caused annual basal area increments of black spruce to more than double (Lieffers and Macdonald, 1990) and annual tree ring growth to increase by several times (Dang and Lieffers, 1989) at different boreal sites. More rapid nutrient uptake and growth with lower water tables have been attributed to higher soil temperatures (Lieffers and Rothwell, 1987) and lower soil water contents (Lieffers, 1988). More rapid nutrient uptake and growth can also be attributed to more rapid root $\mathrm{O}_{2}$ uptake and hence activity, particularly in roots with low internal porosity which rely more on soil transport for $\mathrm{O}_{2}$ uptake. However, in soils with rapid drainage and low water holding capacity, lower water tables can reduce productivity by causing surface drying and hence water stress in shallow-rooted vegetation such as moss (Dimitrov et al., 2011).

Responses of respiration and productivity to changes in water table thus depend upon soil and plant properties as well as on WTD, and consequently differ among wetlands (Adkinson et al., 2011; Sulman et al., 2010). Mathematical models may provide a means to understand and eventually to predict these responses, but only if they represent the basic processes by which these responses are determined. Water table effects on soil respiration are usually represented in models by lower rate constants for anoxic decomposition (Clymo, 1992; St-Hilaire et al., 2010), or by scalar functions that reduce rate constants for decomposition at high soil water contents or potentials (e.g. Bond-Lamberty et al., 2007; Zhang et al., 2002). Water table effects on productivity are sometimes represented by time-dependent scalar functions that reduce productivity in wet soils through a driver variable such as stomatal conductance (e.g. Bond-Lamberty et al., 2007; Sonnentag et al., 2008). However, these scalar functions do not simulate the physical and biological processes by which suppression of decomposition and productivity occur in wetland soils, but rather the effects of these processes.
Even so, these functions are not widely implemented in mathematical models used to study ecosystem behavior. In a recent review of seven widely used ecosystem models, Sulman et al. (2012) found only one which included processes to limit productivity in wet soils. Furthermore, most ecosystem models do not simulate the hydrological processes that control WTD and hence the soil wetness that drives these functions, but rather require WTD as an input (e.g. St-Hilaire et al., 2010; Frolking et al., 2002). This requirement limits the predictive capabilities of these models.

The key processes needed in models used for studies of wetland productivity are the transport, uptake and reduction of $\mathrm{O}_{2}$ in soil as affected by soil water content. Higher water tables are thought to decrease respiration by reducing $\mathrm{O}_{2}$ uptake used to drive oxidation-reduction reactions by soil microbes and roots. Energy yield from oxidation when coupled to reduction of $\mathrm{O}_{2}$ exceeds that from oxidation when coupled to reduction of other electron acceptors (Brock and Madigan, 1991). Reduced $\mathrm{O}_{2}$ uptake therefore slows processes driven by this energy, including microbial and root growth, decomposition and nutrient mineralization, and hence nutrient uptake and plant productivity. On the other hand, lower water tables are thought to decrease respiration by reducing microbial access to substrate in desiccated near-surface soil (Dimitrov et al., 2010a), thereby slowing oxidationreduction reactions and hence microbial growth and activity. Models used to study water table effects on wetland respiration and productivity therefore should explicitly simulate (1) the transformations and energy yields of oxidationreduction reactions by microbes and roots, (2) controls on the rates of these reactions exerted by the transfers of water and of the reactants and products of these reactions, particularly $\mathrm{O}_{2}$, through soil and roots, and (3) the effects of these reactions on soil nutrient transformations and root nutrient uptake. These reactions, as well as their controls and effects, need to be simulated in dynamic aerobic and anaerobic zones determined by water table position calculated from vertical and lateral water transfers.

These processes are implemented to varying degrees in transient variably saturated flow models (e.g. Langergraber and Šimůnek, 2005) used to study respiration in constructed wetlands. The full implementation of these processes would avoid the arbitrary scalar functions described above which are used to represent these effects in some current ecosystem models. Such implementation is attempted in the general-purpose model ecosys, in which a comprehensive set of oxidation-reduction reactions in soil (obligate aerobic, facultative anaerobic and obligate anaerobic heterotrophic decomposition, heterotrophic and autotrophic methanogenesis, autotrophic methanotrophy, autotrophic nitrification and heterotrophic diazotrophy) and roots are calculated from reaction kinetics driven by oxidation-reduction energy yields (Grant, 1998, 1999; Grant and Pattey, 2003; Grant et al., 2006, 2009b, 2009a, 2010a, b). All reactants and products of these reactions undergo convective-dispersive 
transfer through, and volatilization-dissolution exchange between, gaseous and aqueous phases of soil and roots in three-dimensional soil landscapes, thereby controlling aqueous concentrations and hence oxidation-reduction rates (Dimitrov et al., 2010a, 2011; Grant, 2004; Grant and Roulet, 2002). These rates drive those of soil nutrient transformations and hence root nutrient uptake, thereby controlling primary productivity (Grant et al., 2009a, 2010a, b). All algorithms used to simulate these transformations and transfers are parameterized from basic research conducted independently of the model, allowing ecosys to avoid arbitrary parameterizations of anaerobic effects on respiration and productivity used in earlier models. Furthermore, the model includes a full set of vertical and lateral water flows used to calculate WTD (Dimitrov et al., 2010b; Grant, 2004), enabling the simulation of all key processes by which WTD affects wetland respiration and productivity.

The absence of these processes in most ecosystem models prevents them from simulating changes in respiration and productivity observed with changes in WTD, limiting their ability to simulate wetland behavior (Sulman et al., 2012). The objective of this study is to determine whether implementing these processes in a more detailed ecosystem model such as ecosys would enable simulation of the complex changes in wetland respiration and productivity observed with changes in WTD. For example, with greater WTD the model should be able to simulate increases in respiration from more rapid $\mathrm{O}_{2}$ uptake and reduction under some conditions, but decreases in respiration from soil drying under others. With greater WTD the model should also be able to simulate increases in productivity from more rapid nutrient mineralization and uptake under some conditions, but reduced productivity from water stress under others. To accomplish this, $\mathrm{CO}_{2}$ fluxes modelled over a shrub fen at Lost Creek, WI were compared with those measured by eddy covariance (EC) at hourly, seasonal and annual time scales during several years with differing temperature, precipitation and WTD.

\section{Methods}

\subsection{Model development}

\subsubsection{General}

The key algorithms governing the modelling of ecological controls on $\mathrm{CO}_{2}$ exchange in ecosys are described in the Supplement to this article, in which equations and variables referenced below are described and listed in Appendices A through F. Algorithms which govern the transport, uptake and reduction of $\mathrm{O}_{2}$ in soil are particularly relevant to controls on $\mathrm{CO}_{2}$ exchange in wetlands, and so are described here in further detail. All model parameters in ecosys are derived from independent experiments and so remain unchanged in this study from those used in earlier studies (e.g. Dimitrov et al., 2010a, b, 2011; Grant, 2004; Grant et al., 2009a, b, 2010a, b, 2011, 2012) as given in the Supplement.

\subsubsection{Heterotrophic respiration}

Organic transformations in ecosys occur in five organic matter-microbe complexes (coarse woody litter, fine nonwoody litter, animal manure, particulate organic carbon (POC), and humus), each of which consists of five organic states (three decomposition substrates: solid organic $\mathrm{C}$, sorbed organic $\mathrm{C}$ and microbial residue $\mathrm{C}$, as well as the decomposition product: dissolved organic C (DOC), and the decomposition agent: microbial biomass) in a surface residue layer and in each soil layer. The decomposition rates of each of the three substrates and resulting production of DOC in each complex is a first-order function of the active biomasses $M$ of diverse heterotrophic microbial functional types, including obligate aerobes (bacteria and fungi), facultative anaerobes (denitrifiers), obligate anaerobes (fermenters), heterotrophic (acetotrophic) and autotrophic (hydrogenotrophic) methanogens, and aerobic and anaerobic heterotrophic diazotrophs (non-symbiotic $\mathrm{N}_{2}$ fixers) [A1, A2]. Decomposition rates are also Monod functions of substrate $\mathrm{C}$ concentrations in soil [A3], calculated from the fraction of substrate mass colonized by $M$ [A4].

Growth of $M$ by each microbial functional type [A25] is calculated from its uptake of DOC [A21], driven by energy yields from growth respiration $\left(R_{\mathrm{g}}\right)$ [A20] remaining after subtracting maintenance respiration $\left(R_{\mathrm{m}}\right)$ [A18] from heterotrophic respiration $\left(R_{\mathrm{h}}\right)$ [A11] driven by DOC oxidation [A13]. This oxidation may be limited by microbial $\mathrm{O}_{2}$ reduction [A14] driven from microbial $\mathrm{O}_{2}$ demand [A16] and constrained by aqueous $\mathrm{O}_{2}$ concentrations $\left(\left[\mathrm{O}_{2 \mathrm{~s}}\right]\right)$ [A17]. These concentrations are maintained by convectivedispersive transport of $\mathrm{O}_{2}$ from the atmosphere to gaseous and aqueous phases in the soil surface layer [D15], by convective-dispersive transport of $\mathrm{O}_{2}$ through gaseous and aqueous phases in adjacent soil layers [D16, D19], and by dissolution of $\mathrm{O}_{2}$ from gaseous to aqueous phases within each soil layer [D14a].

Under dryland conditions, rapid $\mathrm{O}_{2}$ diffusivity in the gaseous phase $\left(D_{\mathrm{g}}\right.$ in [D17]) allows $\mathrm{O}_{2}$ demand by aerobic functional types to be met almost entirely from $\left[\mathrm{O}_{2 s}\right]$ [A17] as long as some air-filled porosity $\theta_{\mathrm{g}}$ is present. However, with higher water tables, $\theta_{\mathrm{g}}$ above the water table may decline to values at which $D_{\mathrm{g}}$ may reduce gaseous $\mathrm{O}_{2}$ transport [D16], while $\theta_{\mathrm{g}}$ below the water table is zero and so prevents gaseous $\mathrm{O}_{2}$ transport. Under these conditions, $\left[\mathrm{O}_{2 \mathrm{~s}}\right]$ relies more on $\mathrm{O}_{2}$ transport through the slower aqueous phase [D19]. Consequent declines in $\left[\mathrm{O}_{2 \mathrm{~s}}\right]$ slow $\mathrm{O}_{2}$ uptake [A17] and hence $R_{\mathrm{h}}$ [A14], $R_{\mathrm{g}}$ [A20] and growth of $M$ [A25]. Lower $M$ in turn slows decomposition of organic $\mathrm{C}$ [A1, A2] and production of DOC, which further slows $R_{\mathrm{h}}$ [A13], $R_{\mathrm{g}}$ and growth of $M$. Although some microbial 
functional types can sustain DOC oxidation by reducing alternative electron acceptors (e.g. methanogens reducing acetate or $\mathrm{CO}_{2}$ to $\mathrm{CH}_{4}$ in Grant, 1998, and denitrifiers reducing $\mathrm{NO}_{\mathrm{x}}$ to $\mathrm{N}_{2} \mathrm{O}$ or $\mathrm{N}_{2}$ in Grant et al., 2006), lower energy yields from these reactions reduce DOC uptake from $R_{\mathrm{g}}$, and hence $M$ growth, organic $\mathrm{C}$ decomposition and subsequent DOC oxidation. Slower decomposition of organic $\mathrm{C}$ under low $\left[\mathrm{O}_{2 \mathrm{~s}}\right]$ also causes slower decomposition of organic $\mathrm{N}$ and P [A7] and production of DON and DOP, which causes slower uptake [A22] and growth [A29] of microbial $\mathrm{N}$ and $\mathrm{P}$. This slower growth causes slower mineralization of $\mathrm{NH}_{4}^{+}$, $\mathrm{NO}_{3}^{-}$and $\mathrm{H}_{2} \mathrm{PO}_{4}^{-}$[A26], and hence lower aqueous concentrations.

\subsubsection{Autotrophic respiration}

Growth of root and shoot phytomass in each plant population is calculated from its assimilation of the nonstructural $\mathrm{C}$ product of $\mathrm{CO}_{2}$ fixation $\left(\sigma_{\mathrm{C}}\right)$ [C20]. Assimilation is driven by growth respiration $\left(R_{\mathrm{g}}\right)$ [C17] remaining after subtracting maintenance respiration $\left(R_{m}\right)$ [C16] from autotrophic respiration $\left(R_{\mathrm{a}}\right)$ [C13] from oxidation of $\sigma_{C}$ [C14]. This oxidation in roots may be limited by root $\mathrm{O}_{2}$ reduction [C14b] which is driven by root $\mathrm{O}_{2}$ demand to sustain $\mathrm{C}$ oxidation and nutrient uptake [C14e], and constrained by $\mathrm{O}_{2}$ uptake controlled by concentrations of aqueous $\mathrm{O}_{2}$ in the soil $\left(\left[\mathrm{O}_{2 \mathrm{~s}}\right]\right)$ and roots $\left(\left[\mathrm{O}_{2 \mathrm{r}}\right]\right)[\mathrm{C} 14 \mathrm{~d}]$. Values of $\left[\mathrm{O}_{2 \mathrm{~s}}\right]$ are maintained by convective-dispersive transport of $\mathrm{O}_{2}$ through soil gaseous and aqueous phases and by dissolution of $\mathrm{O}_{2}$ from soil gaseous to aqueous phases through processes analogous to those described under Heterotrophic Respiration above. Values of $\left[\mathrm{O}_{2 \mathrm{r}}\right]$ are maintained by convective-dispersive transport of $\mathrm{O}_{2}$ through the root gaseous phase [D16d] and by dissolution of $\mathrm{O}_{2}$ from root gaseous to aqueous phases [D14b]. This transport depends on species-specific values used for root air-filled porosity $\left(\theta_{\mathrm{pr}}\right)[\mathrm{D} 17 \mathrm{~b}]$.

Under dryland conditions, rapid $\mathrm{O}_{2}$ diffusivity in the soil gaseous phase usually allows root $\mathrm{O}_{2}$ demand to be almost entirely met from $\left[\mathrm{O}_{2 \mathrm{~s}}\right][\mathrm{C} 14 \mathrm{c}, \mathrm{d}]$ as long as some air-filled porosity $\theta_{\mathrm{g}}$ is present. However, with higher water tables, reduced soil $\mathrm{O}_{2}$ transport forces root $\mathrm{O}_{2}$ uptake to rely more on $\left[\mathrm{O}_{2 \mathrm{r}}\right]$ and hence on root $\mathrm{O}_{2}$ transport. If this transport is inadequate, declines in $\left[\mathrm{O}_{2 \mathrm{r}}\right]$ slow $\mathrm{O}_{2}$ uptake $[\mathrm{C} 14 \mathrm{c}, \mathrm{d}]$ and hence $R_{\mathrm{a}}$ [C14b], $R_{\mathrm{g}}$ [C17] and root growth [C20b].

\subsubsection{Primary productivity}

When higher water tables reduce soil $\mathrm{O}_{2}$ transport and root $\mathrm{O}_{2}$ uptake, commensurate reductions in root $\mathrm{C}$ oxidation slow root growth and root $\mathrm{N}$ and $\mathrm{P}$ uptake [C23b, d, f]. Root uptake is further slowed by reductions in aqueous concentrations of $\mathrm{NH}_{4}^{+}, \mathrm{NO}_{3}^{-}$and $\mathrm{H}_{2} \mathrm{PO}_{4}^{-}$[C23a, c, e] from slower mineralization of organic $\mathrm{N}$ and $\mathrm{P}$ as described in Heterotrophic Respiration above. Slower root uptake reduces concentrations of nonstructural $\mathrm{N}$ and $\mathrm{C}$ products of root up- take $\left(\sigma_{N}\right.$ and $\left.\sigma_{\mathrm{P}}\right)$ with respect to that of $\sigma_{\mathrm{C}}$ in leaves [C11], thereby slowing $\mathrm{CO}_{2}$ fixation [C6] and hence productivity.

Thus, water table effects on $R_{\mathrm{h}}, R_{\mathrm{a}}$ and productivity in ecosys are not explicitly parameterized from ecosystem-level observations, but instead are governed by $\mathrm{O}_{2}$ transport and uptake through processes parameterized from basic research.

\subsubsection{Water table depth}

The position of the water table arises from influxes vs. effluxes of water in vertical and lateral directions within the landscape and through surface and subsurface boundaries in one-, two- or three-dimensions. Vertical surface boundary influxes from precipitation or irrigation are provided as inputs to the model. Vertical surface boundary effluxes from transpiration [B1] and evaporation [D6] are calculated from energy balances for canopy, snow, residue and soil surfaces [D11] coupled with subsurface water transfers through root [B5] and soil [D7] profiles. Lateral surface runoff within the landscape and across lower surface boundaries is modelled using Manning's equation [D1] with surface water velocity [D3] calculated from surface geometry [D5] and slope [D6], and with surface water depth [D2] calculated from surface water balance [D4] using kinematic wave theory. Vertical and lateral subsurface water flows within the landscape [D7] are calculated from Richard's equation using bulk soil water potentials $\psi_{\mathrm{s}}$ of adjacent cells if both source and destination cells are unsaturated [D9a], or from Green-Ampt equation using $\psi_{\mathrm{s}}$ beyond the wetting front of the unsaturated cell if either source or destination cell is saturated [D9b] (Grant et al., 2004). Vertical and lateral subsurface water flows can also occur within the landscape through macropores using Poiseulle-Hagen theory for laminar flow in tubes, depending on inputs for macropore volume fraction (Dimitrov et al., 2010b).

Lateral flows through subsurface boundaries are controlled by the depth of and distance to an external water table used to represent watershed effects on landscape hydrology (Fig. 1). The depth of this external water table is calculated as the average of a fixed value provided to the model, and the WTD in the boundary grid cells through which lateral flows occur. The external water table can therefore rise and fall with changes in landscape surface water exchange. Lateral subsurface flows from boundary grid cells are calculated from their $\psi_{\mathrm{s}}$ and lateral hydraulic conductivities, and from external hydraulic gradients determined by elevation differences and lateral distances between these grid cells and the external water table [D10]. The WTDs within the boundary grid cells are calculated from the uppermost position in the soil profiles at which discharge to, or recharge from, the external water table is occurring. The WTDs in the modelled landscape are not therefore prescribed, but are controlled by vertical surface boundary fluxes, and by lateral surface and subsurface boundary fluxes. 


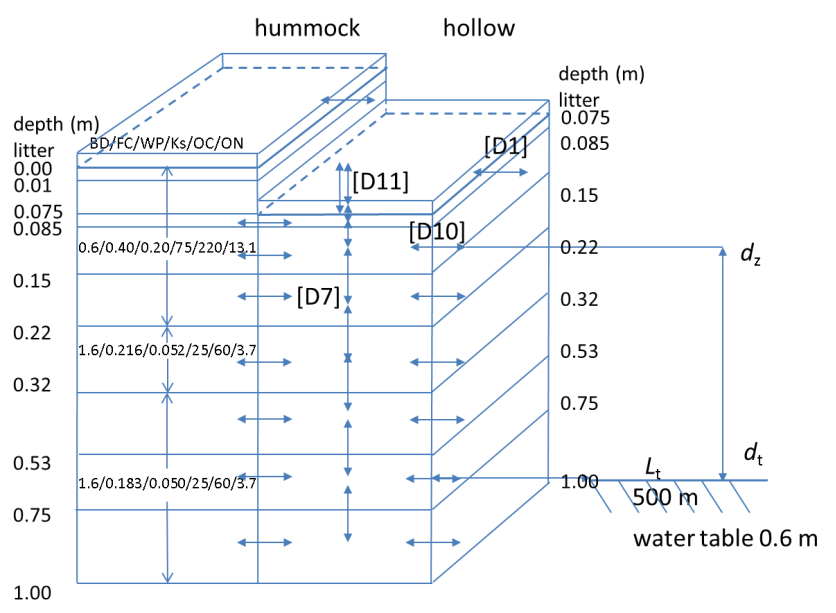

Fig. 1. Schematic representation of wetland landscape in ecosys. Depths are from the hummock surface to the bottom of each soil layer. Numbers in each soil layer are BD: Bulk density $\left(\mathrm{Mg} \mathrm{m}^{-3}\right)$, FC: field capacity $\left(\mathrm{m}^{3} \mathrm{~m}^{-3}\right)$, WP: wilting point $\left(\mathrm{m}^{3} \mathrm{~m}^{-3}\right)$, Ks: saturated hydraulic conductivity $\left(\mathrm{mm} \mathrm{h}^{-1}\right)$, OC: organic carbon $\left(\mathrm{kg} \mathrm{Mg}^{-1}\right), \mathrm{ON}$ : organic nitrogen $\left(\mathrm{kg} \mathrm{Mg}^{-1}\right)$. Values for $\mathrm{BD}, \mathrm{OC}$ and $\mathrm{ON}$ were measured at the field site. Values for FC, WP and Ks in the organic layers were derived from generalized relationships in Boelter 1969) and Päivänen (1973), and those in the mineral layers from pedotransfer functions in Saxton et al. (1986). $L_{\mathrm{t}}$ is distance to the external water table, $d_{\mathrm{z}}$ and $d_{\mathrm{t}}$ are depths of the internal (variable) and external (constant) water tables. Expressions in square brackets refer to equations in the Supplement by which indicated fluxes are calculated.

\subsection{Model experiment}

\subsubsection{Site conditions}

Model algorithms for the effects of hydrology on wetland respiration and productivity were tested with $\mathrm{CO}_{2}$ fluxes measured by EC over a minerotrophic wetland dominated by alder (Alnus incana sp. rugosa) and willow (Salix sp.) shrubs with an understory of sedges (Carex sp.), near Lost Creek, WI $\left(46^{\circ} 4.90^{\prime} \mathrm{N}, 89^{\circ} 58.70^{\prime} \mathrm{W}\right)$ during six years (2001-2006) with contrasting weather and hydrology. The site and EC flux measurements are described in further detail by Sulman et al. (2009).

\subsubsection{Model runs}

Wetland microtopography was simulated by two interconnected soil profiles representing a hummock and a hollow, with equal areas and identical properties except for the absence of the upper $0.075 \mathrm{~m}$ in the hollow (Fig. 1). Based on site observations of WTD, the external water table was set to a depth of $0.6 \mathrm{~m}$ at a distance of $500 \mathrm{~m}$ from the modelled landscape (Fig. 1). Both the hummock and the hollow were seeded with the same populations of shrubs and sedges, properties of which were unchanged from those in earlier studies (e.g. Dimitrov et al., 2011; Grant et al., 2003, 2011, 2012). Shrubs and sedges used common values for parameters in all autotrophic $\mathrm{C}$ transformations [C1-C23], except for 0.1 and 0.2 (Visser et al., 2000), respectively, for $\theta_{\mathrm{pr}}$ in root $\mathrm{O}_{2}$ transport [D17d]. The model was run for $105 \mathrm{yr}$ under repeating 7-yr sequences of hourly-averaged weather data (solar radiation, air temperature, wind speed, humidity and precipitation) recorded at nearby Willow Creek in 2000, and at Lost Creek from 2001 to 2006. This period allowed $\mathrm{CO}_{2}$ exchange in the model to achieve stable values through successive weather sequences. Model results for the final $6 \mathrm{yr}$ of the run were compared with measurements at Lost Creek from 2001 to 2006.

\subsubsection{Model testing}

Hourly $\mathrm{CO}_{2}$ fluxes modelled over the interconnected hummocks and hollows (Fig. 1) were averaged, based on similar areas of hummocks and hollows observed at the experimental site, and then regressed on hourly-averaged $\mathrm{EC} \mathrm{CO}_{2}$ fluxes, of which both 1/2-hourly values were measured rather than gap-filled, for each year of measurement. Model performance was evaluated from regression intercepts $(a \rightarrow 0)$, slopes $(b \rightarrow 1)$ and correlation coefficients $\left(R^{2} \rightarrow 1\right)$.

\subsubsection{Model sensitivity to WTD}

To examine sensitivity of modelled $\mathrm{CO}_{2}$ exchange and productivity to changes in WTD, the final $6 \mathrm{yr}$ of the model run described above were repeated with the depth of the external water table raised from 0.6 to $0.3 \mathrm{~m}$, or lowered to $0.9 \mathrm{~m}$, but with everything else unchanged.

\section{Results}

\subsection{Modelled vs. measured $\mathrm{CO}_{2}$ fluxes}

Regressions of hourly modelled $\mathrm{CO}_{2}$ fluxes averaged for the interconnected hummocks and hollows vs. hourlyaveraged measured $\mathrm{CO}_{2}$ fluxes gave intercepts within $0.1 \mu \mathrm{mol} \mathrm{m}^{-2} \mathrm{~s}^{-1}$ of zero, and slopes within 0.1 of one, indicating minimal bias in modelled values for all years of the study except 2004 when variation in $\mathrm{CO}_{2}$ fluxes was overestimated (Table 1). Values for coefficients of determination $\left(R^{2}\right)$ and root mean squares for differences between modelled and EC fluxes (RMSD) were ca. $0.7(P<0.0001)$ and $2 \mu \mathrm{mol} \mathrm{m}{ }^{-2} \mathrm{~s}^{-1}$. Much of the unexplained variance in EC fluxes could be attributed to a random error of ca. $20 \%$ in EC methodology (Wesely and Hart, 1985). This attribution was corroborated by root mean squares for error (RMSE) for EC measurements at LC calculated from Richardson et al. (2006) that were similar to RMSD, indicating that further constraint in model testing could not be achieved without further precision in EC measurements. 
Table 1. Statistics from regressions of simulated on measured $(a, b)$, and measured on simulated $\left(R^{2}, \mathrm{RMSD}\right)$, hourly $\mathrm{CO}_{2}$ fluxes over a boreal fen at Lost Creek, WI. All measured values were recorded at $u \cdot>0.2 \mathrm{~m} \mathrm{~s}^{-1}$.

\begin{tabular}{lllllll}
\hline & $n$ & $\begin{array}{l}a^{\dagger} \\
\mu \mathrm{mol} \mathrm{m}{ }^{-2} \mathrm{~s}^{-1}\end{array}$ & $b^{\dagger}$ & $\mathrm{R}^{2 \ddagger}$ & $\begin{array}{l}\mathrm{RMSD}^{\ddagger} \\
\mu \mathrm{mol} \mathrm{m}{ }^{-2} \mathrm{~s}^{-1}\end{array}$ & $\begin{array}{l}\mathrm{RMSE}^{\mathrm{II}} \\
\mu \mathrm{mol} \mathrm{m}^{-2} \mathrm{~s}^{-1}\end{array}$ \\
\hline 2001 & 6366 & 0.0 & 0.94 & 0.65 & 2.1 & 2.2 \\
2002 & 6796 & 0.0 & 1.05 & 0.75 & 1.9 & 2.1 \\
2003 & 5509 & -0.1 & 0.96 & 0.72 & 2.2 & 2.5 \\
2004 & 4695 & -0.2 & 1.22 & 0.73 & 1.5 & 2.2 \\
2005 & 4251 & 0.1 & 0.98 & 0.72 & 2.7 & 2.5 \\
2006 & 4576 & 0.1 & 1.06 & 0.73 & 2.5 & 2.4 \\
\hline
\end{tabular}

${ }^{\dagger} Y=a+b X$ from regression of simulated $Y$ on measured $X$.

$* R^{2}=$ coefficient of determination and RMSD $=$ root mean square for difference from regression of measured $Y$ on simulated $X$.

$\mathbb{I}_{\text {RMSE }}$ root mean square for error of measured fluxes calculated from Richardson et al. (2006).

\subsection{Water table and seasonal net ecosystem productivity}

The water table measured at Lost Creek from 2001 to 2006 typically remained within $0.2 \mathrm{~m}$ of hummock surfaces until May, but descended to depths varying from 0.4 to $0.7 \mathrm{~m}$ during July through September before rising gradually thereafter (Fig. 2). These seasonal trends in WTD were simulated from transfers of water in vertical [B1] and lateral [D1, D10] directions through surface and subsurface boundaries (Fig. 1) as described in Sect. 2.1 above. WTD in the model was close to that measured in unfrozen soil during most years, but remained lower than that measured in unfrozen soil during 2001 and 2003, and in frozen soil during most years of the study (Fig. 2). The greater WTD modelled in frozen soil was attributed to slow subsurface recharge of soil water drawn to near-surface freezing zones with lower $\psi_{\mathrm{s}}$.

Net ecosystem productivity (NEP), calculated from daily sums of gap-filled EC fluxes at Lost Creek from 2001 through 2006, remained negative (net C emissions) until warming in May, rose rapidly during late May and June to reach $2-4 \mathrm{~g} \mathrm{C} \mathrm{m}^{-2} \mathrm{~d}^{-1}$ (net $\mathrm{C}$ uptake) during late June and July, then declined gradually during August, becoming negative again after late September (Fig. 2). These seasonal trends in NEP were modelled from changes in net $\mathrm{CO}_{2}$ exchange driven by those in GPP [C1], $R_{\mathrm{a}}$ [C13] and $R_{\mathrm{h}}$ [A11] with changes in weather and hydrology, as described in Sect. 2.1 above. Because $\mathrm{CO}_{2}$ fluxes in the model were consistent with those measured by EC (Table 1), net $\mathrm{C}$ uptake modelled during growing seasons was similar to that calculated from gapfilled EC. However, net $\mathrm{C}$ emissions modelled during late spring and early autumn were consistently larger than those calculated from gap-filled EC.

\subsection{Water table and diurnal $\mathrm{CO}_{2}$ exchange}

Changes in WTD were found to have contrasting effects on ecosystem $\mathrm{CO}_{2}$ exchange, depending on the WTD at which changes occurred. To investigate relationships between WTD and ecosystem $\mathrm{CO}_{2}$ exchange, diurnal $\mathrm{CO}_{2}$ fluxes were examined during selected intervals with different WTD and weather in 2002 and 2006, when seasonal WTD was shallowest and deepest, respectively, during the study period (Fig. 2e, q).

These fluxes were first examined during mid-May 2002 vs. 2006 when the water table was shallowest (Fig. 2e, q) and the weather was cool (Fig. 3a,d). Only very low $\mathrm{CO}_{2}$ influxes and effluxes were modelled and measured in 2002 (Fig. 3c) when the water table was near the surface (Fig. 2e). Larger $\mathrm{CO}_{2}$ influxes and effluxes were modelled and to a lesser extent measured under comparable weather (similar range of radiation and temperature in Fig. 3a, d) in 2006 (Fig. 3f) when the water table was about $0.2 \mathrm{~m}$ below the surface (Fig. 2q). In both years, low LE effluxes modelled and measured during May delayed soil drying and water table decline.

$\mathrm{CO}_{2}$ fluxes were then examined during mid-August 2002 vs. 2006 when WTD and weather were near respective seasonal averages (Fig. 4). $\mathrm{CO}_{2}$ effluxes modelled over a WTD just below $0.2 \mathrm{~m}$ in 2002 (Fig. 2e) were slightly less than those modelled under comparable weather conditions (similar radiation and temperature in Fig. 4a, d) over a WTD of $0.7 \mathrm{~m}$ in 2006 (Fig. 2q) (-4 vs. $-5 \mu \mathrm{mol} \mathrm{m}^{-2} \mathrm{~s}^{-1}$ in Fig. 4c vs. f). Peak $\mathrm{CO}_{2}$ influxes modelled over the shallower water table in 2002 were slightly smaller than those over the deeper water table in 2006 (13 vs. $14 \mu \mathrm{mol} \mathrm{m}^{-2} \mathrm{~s}^{-1}$ in Fig. 4c vs. f), even though greater effluxes of LE vs. H indicated better hydration in 2002 (Fig. 4b vs. e). In both years $\mathrm{CO}_{2}$ influxes and effluxes modelled over hollows were smaller than those over hummocks (Fig. 4c, f) because the hollow surface was $0.075 \mathrm{~m}$ closer to the water table of the interconnected hummock and hollow (Fig. 1). However, these small differences in $\mathrm{CO}_{2}$ fluxes modelled with landscape position or WTD could not be clearly resolved in the EC measurements.

$\mathrm{CO}_{2}$ fluxes were then examined during late June-early July 2002 vs. 2006 when different WTD under comparable warming events (Fig. 5a, d) enabled interactive effects of WTD and temperature on $\mathrm{CO}_{2}$ exchange to be investigated (Fig. 5c, f). Warming in 2002 over a WTD just above $0.2 \mathrm{~m}$ (Fig. 2e) caused rises in LE but not in $\mathrm{H}$ (Fig. 5b), indicating that the fen surface remained well hydrated. Warming also caused sharp rises in $\mathrm{CO}_{2}$ effluxes and only slight declines $\mathrm{CO}_{2}$ influxes (Fig. 5c), indicating that both respiration and productivity, estimated from differences between diurnal influxes and effluxes, rose with warming over a shallower water table. However, the same warming in 2006 over a WTD of ca. $0.7 \mathrm{~m}$ (Fig. 2q) during a dry period (Fig. 2p) caused much smaller rises in LE, and larger rises in $\mathrm{H}$ (Fig. 5e), indicating some drying of the fen surface. In both years, Bowen ratios $(\beta=\mathrm{H} / \mathrm{LE})$ declined as LE rose with warming at hourly and daily time scales, but remained consistently larger in 2006 vs. 2002 (Fig. 6b vs. a), indicating constraints on LE imposed by soil drying over the deeper water table. Warming in 2006 caused much smaller rises in $\mathrm{CO}_{2}$ effluxes, but sharper declines in $\mathrm{CO}_{2}$ influxes than did similar warming in 2002 (Fig. 5f), indicating that both 

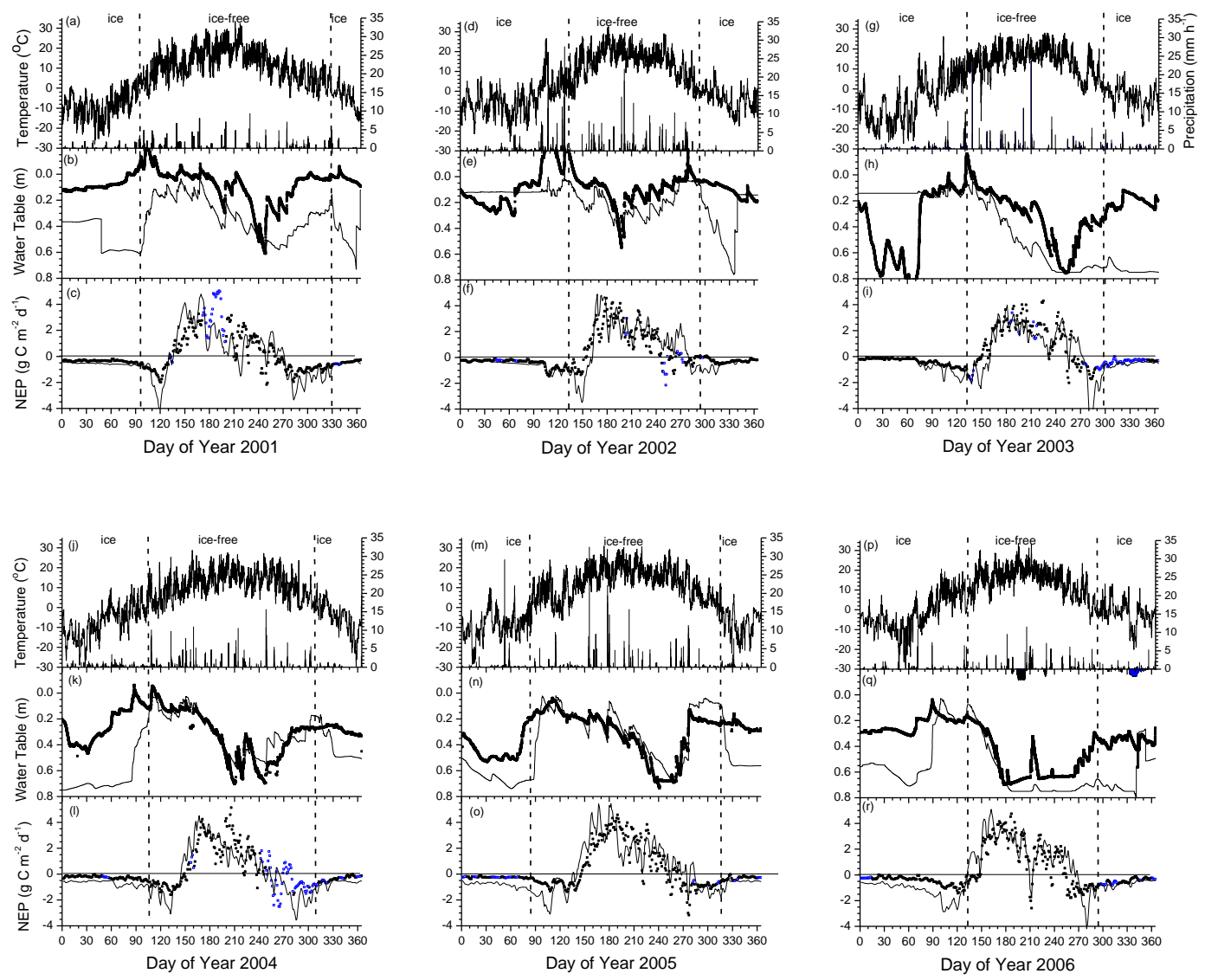

Fig. 2. Hourly air temperatures and precipitation, water table depth and net ecosystem productivity measured (symbols) and modelled (lines) from 2001 to 2006 at Lost Creek, WI. Open symbols represent daily totals calculated from more than 24 gap-filled 1/2-hourly values.

respiration and productivity were constrained by soil drying during warming over a deeper water table. Thus, $\mathrm{CO}_{2}$ exchange responded differently to a lower water table under warmer weather, which induced surface drying (Fig. 5), than under cooler weather, which did not (Figs. 3 and 4). The constraint of surface drying on $R_{\mathrm{h}}$ was later alleviated by several precipitation events (Fig. 7a) that raised effluxes of LE vs. H (Fig. 7b), and sharply raised effluxes of $\mathrm{CO}_{2}$, causing a brief but pronounced decline in NEP (Fig. 2f).

The effects of WTD on $\mathrm{CO}_{2}$ effluxes in Figs. 3-5 were modelled through the effects of WTD on $\left[\mathrm{O}_{2 \mathrm{~s}}\right]$. The nearsurface water table in May 2002 (Fig. 2e) caused $\left[\mathrm{O}_{2 \mathrm{~s}}\right]$ in the model to decline sharply with depth under hummocks and hollows (Fig. 8a), thereby strongly limiting $\mathrm{C}$ oxidation and hence $\mathrm{CO}_{2}$ effluxes (Fig. 3c). The slightly deeper water table in May 2006 (Fig. 2q) caused $\left[\mathrm{O}_{2 \mathrm{~s}}\right]$ to decline slightly less sharply with depth, partially alleviating $\mathrm{O}_{2}$ limitation to $\mathrm{C}$ oxidation (Fig. 3f). Deepening water tables in summer 2002 allowed $\left[\mathrm{O}_{2 \mathrm{~s}}\right.$ ] to decline less sharply with depth than in May (Fig. 8b, c), enabling more rapid $\mathrm{C}$ oxidation (Figs. $4 \mathrm{c}$ and 5c). The very deep water tables in summer 2006 (Fig. 2q) allowed $\left[\mathrm{O}_{2 \mathrm{~s}}\right]$ to remain close to atmospheric equivalents through most of the rooting zone (Fig. 8b,c), largely alleviat- ing $\mathrm{O}_{2}$ limitation to $\mathrm{C}$ oxidation (Figs. $4 \mathrm{f}$ and $5 \mathrm{f}$ ). The sharp declines in $\left[\mathrm{O}_{2 \mathrm{~s}}\right]$ in the model occurred at depths which corresponded to those of the water table (Fig. 2), indicating the effectiveness of saturated soil in reducing $\mathrm{O}_{2}$ concentrations.

\subsection{Water table and annual $\mathrm{C}$ balances}

Annual totals of GPP, $R_{\mathrm{a}}$, NPP and $R_{\mathrm{h}}$ modelled over hummocks and hollows exhibited interannual variability associated with mean annual temperature (MAT), precipitation, WTD and landscape position (Table 2). Annual NPP modelled in 2001 gave peak above-ground phytomasses for shrubs and sedges averaged for hummocks and hollows of 401 and $110 \mathrm{~g} \mathrm{C} \mathrm{m}^{-2}$, comparable to ones of 414 and $79 \mathrm{~g} \mathrm{C} \mathrm{m}^{-2}$ (assuming $50 \% \mathrm{C}$ in DM) reported in Sulman et al. (2009). Losses of $\mathrm{CH}_{4}$ and of dissolved organic and inorganic C (DOC and DIC) also varied with MAT, precipitation, WTD and landscape position (Table 2), and caused net ecosystem $\mathrm{C}$ balance (NECB $=\mathrm{NEP}-\mathrm{CH}_{4}-\mathrm{DOC}-$ DIC) to be $15-25 \%$ less than NEP. Although greater WTD in 2006 vs. 2002 caused diurnal $\mathrm{CO}_{2}$ influxes both to increase (Figs. 3 and 4) and decrease (Fig. 5), depending on WTD and weather, at an annual time scale variation in GPP 

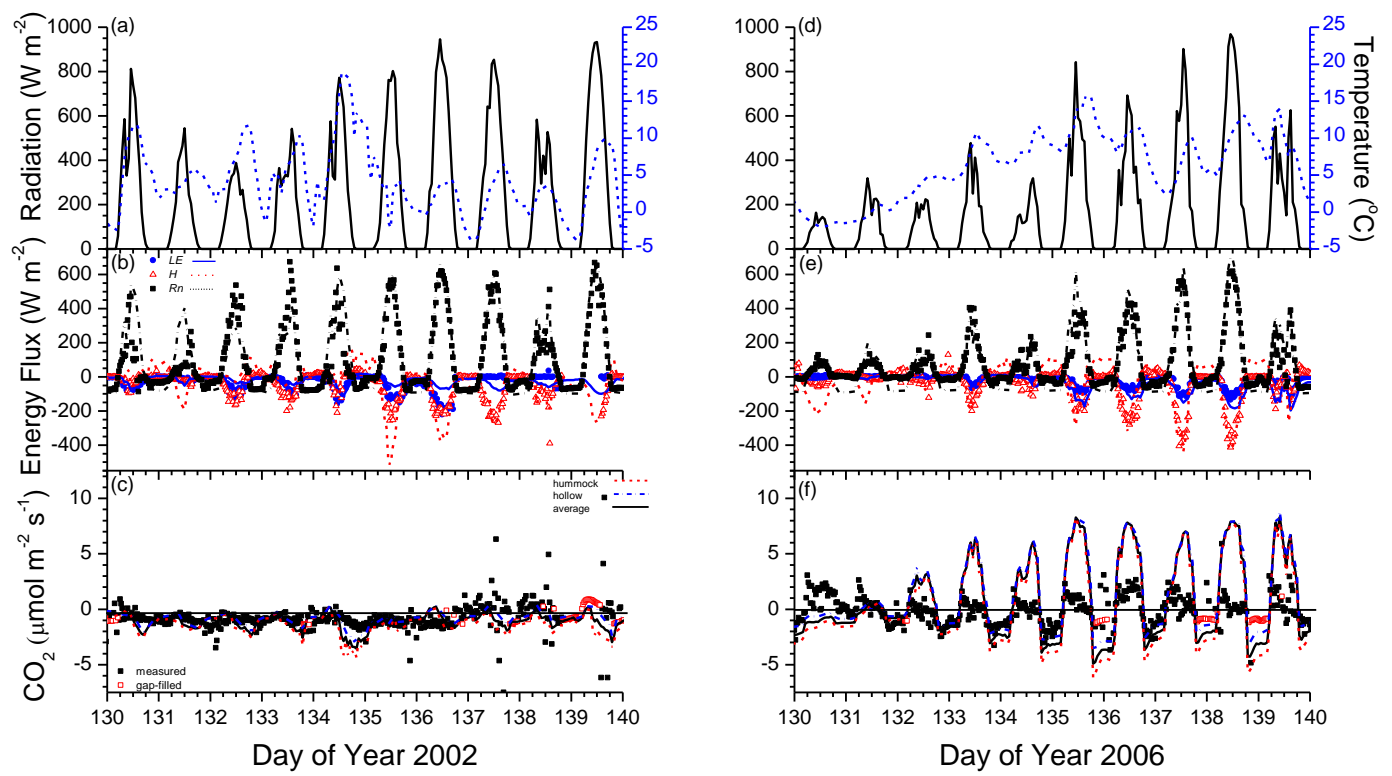

Fig. 3. Radiation and air temperature, energy and $\mathrm{CO}_{2}$ fluxes measured (symbols) and modelled (lines) from DOY 131 to 140 with high water table in 2002 ( $0.0 \mathrm{~m}$ in Fig. 2) and lower water table in 2006 (0.2 m in Fig. 2). Positive values represent downward fluxes, negative values represent upward fluxes.
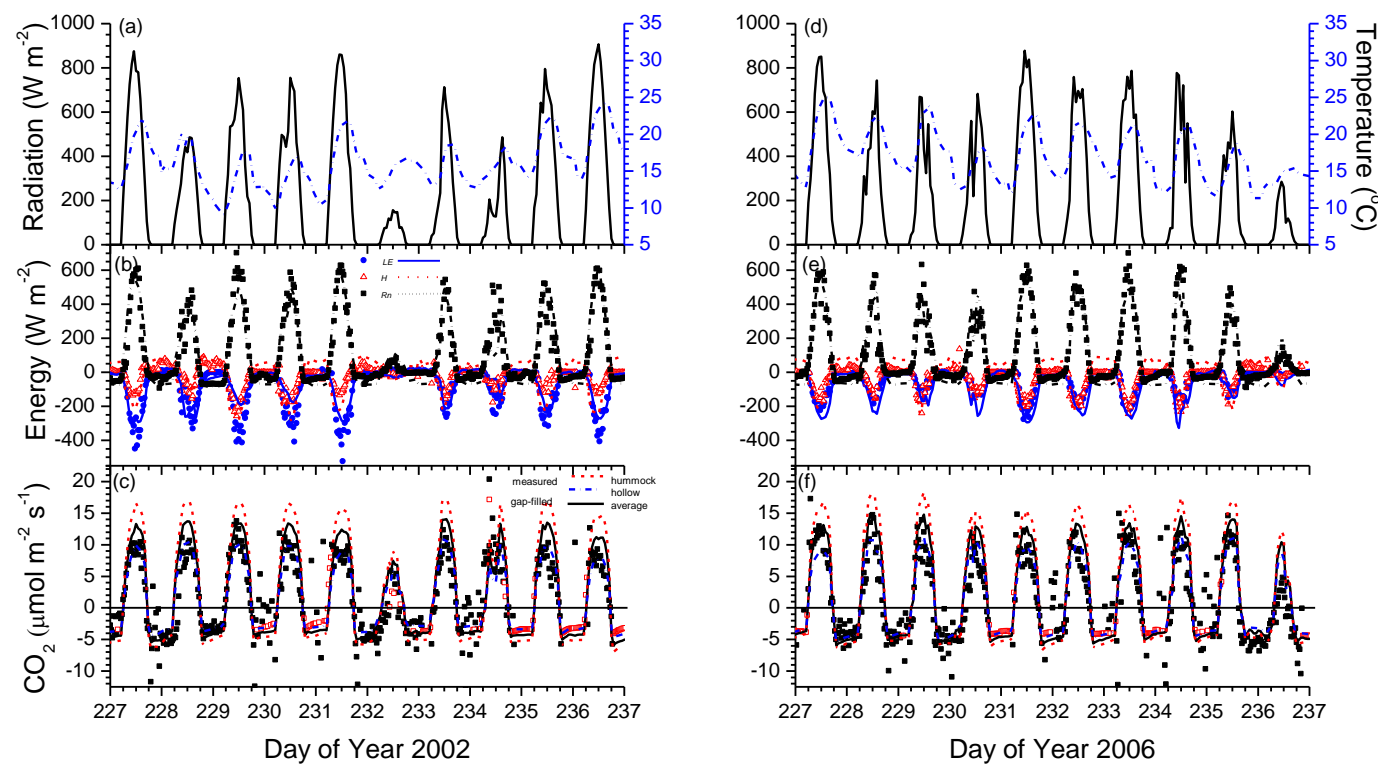

Fig. 4. Radiation and air temperature, energy and $\mathrm{CO}_{2}$ fluxes measured (symbols) and modelled (lines) from DOY 228 to 237 with high water table in 2002 (0.2 m in Fig. 2) and low water table in 2006 (0.7 m in Fig. 2). Positive values represent downward fluxes, negative values represent upward fluxes.

and NPP appeared to be driven more by variation in MAT $\left(R^{2}\right.$ for NPP vs. MAT $\left.=0.91\right)$ than in WTD ( $R^{2}$ for NPP vs. $\mathrm{WTD}=0.05)$. Thus, GPP and NPP declined with MAT from 2001 to 2003 and rose with MAT from 2004 to 2006 (Table 2), as has been modelled and measured at several boreal sites in North America during this period (Grant et al., 2009a, b; Krishnan et al., 2008).
However, variation in annual $R_{\mathrm{h}}$ appeared to be driven more by variation in WTD $\left(R^{2}\right.$ for $R_{\mathrm{h}}$ vs. WTD $\left.=0.31\right)$ than in MAT ( $R^{2}$ for $R_{\mathrm{h}}$ vs. MAT $=0.07$ ) (Table 2 ). Greater WTD in 2006 vs. 2002 caused diurnal $\mathrm{CO}_{2}$ effluxes driven largely by $R_{\mathrm{h}}$ to increase under seasonally average weather (Figs. 3 and 4) and to decrease under warmer weather (Fig. 5). However, these decreases in $\mathrm{CO}_{2}$ effluxes were modelled 
infrequently so that at an annual time scale the shallower water table in 2002 reduced $R_{\mathrm{h}}$ and the deeper water tables thereafter increased $R_{\mathrm{h}}$ (Table 2). Consequently, annual NECB in the model was greatest in 2002 with the shallowest water table and hence lowest $R_{\mathrm{h}}$, and smallest in 2004 with the lowest MAT and hence NPP.

Landscape position had a large effect on ecosystem productivity in the model. Greater annual GPP, $R_{\mathrm{a}}, R_{\mathrm{h}}$ and hence NECB were modelled over greater WTD in hummocks vs. hollows (Table 2), driven by greater diurnal $\mathrm{CO}_{2}$ fluxes (Figs. 3, 4, 5). The greater GPP was attributed to improved nutrient status in hummocks, apparent as greater foliar $\mathrm{N}$ contents in Table 2. This improved nutrient status allowed greater dominance of shrub over sedge, apparent as greater GPP and NPP ratios, to be modelled in hummocks than in hollows (Table 2). Greater effluxes of $\mathrm{CH}_{4}$, DOC and DIC were modelled in years with greater precipitation and shallower water tables such as 2002, and from hollows vs. hummocks in all years of the study (Table 2).

\subsection{Sensitivity of $\mathrm{CO}_{2}$ exchange to water table}

The responses of $\mathrm{CO}_{2}$ exchange to seasonal and interannual changes in WTD (Figs. 1-7) determined those to long-term changes in WTD caused by raising or lowering the external water table. Raising the external water table by $0.3 \mathrm{~m}$ slowed discharge and hastened recharge through the lateral boundaries of the modelled landscape (Fig. 1), and thereby raised the internal water table from that in the earlier model run (Fig. 9a, c). Conversely, lowering the external water table by $0.3 \mathrm{~m}$ hastened discharge and slowed recharge, and thereby lowered the internal water table. Subsidence of the fen surface with drainage was not modelled, so that WTD in these runs referred to an unchanged surface elevation. These changes in WTD had contrasting effects on NEP modelled at different times of the year in 2002 and 2006. In 2002, lowering the water table decreased NEP until the end of June, increased it slightly during July and early August, but decreased it again thereafter (Fig. 9b). In 2006, lowering the water table decreased NEP until the end of May, but increased NEP thereafter (Fig. 9d). In general, lowering the water table reduced NEP when the WTD was less than ca. $0.2 \mathrm{~m}$, and increased NEP when it was greater.

A transition from increases to decreases in NEP with deeper water tables occurred in late August 2002 (Fig. 9b). The cause of this transition was investigated by examining the diurnal $\mathrm{CO}_{2}$ exchange modelled during the period in which the transition occurred (Fig. 10). Lowering the water table (Fig. 10a) increased daytime near-surface soil temperatures (Fig. 10b) and both influxes and effluxes of $\mathrm{CO}_{2}$ (Fig. 10c). Precipitation on DOY 232 (Fig. 2d) raised all water tables by ca. $0.1 \mathrm{~m}$, so that the shallowest water table rose above $0.2 \mathrm{~m}$ (Fig. 10a). This rise caused $\mathrm{CO}_{2}$ effluxes to decrease, and consequently $\mathrm{CO}_{2}$ influxes to increase, over the shallower water table with respect to those over the deeper
(Fig. 10c). These decreased effluxes were modelled from lower $\left[\mathrm{O}_{2 \mathrm{~s}}\right]$ in a shallower aerobic zone following the rise in water table (Fig. 11b vs. a). These changes in $\mathrm{CO}_{2}$ effluxes vs. influxes with WTD caused the transition from increases to decreases in NEP with deeper water tables in late August 2002 (Fig. 9b). Lowering the much deeper water table during the same period in 2006 (Fig. 10d) had little effect on near-surface soil temperatures (Fig. 10e) or on $\mathrm{CO}_{2}$ effluxes (Fig. 10e), but increased $\mathrm{CO}_{2}$ influxes and hence NEP (Fig. 9d).

\subsection{Sensitivity of annual $\mathrm{C}$ balances to watertable}

Responses of NEP to changes in WTD at seasonal (Fig. 9) and diurnal (Fig. 10) time scales were aggregated to the annual time scale for 2001 to 2006 in Table 3. Lowering the water table increased GPP and NPP of shrub, and to a lesser extent of sedge, in each year of the study. Lowering the water table also increased $R_{\mathrm{h}}$ in each year of the study, but more in years with shallow water tables such as 2002 (as in Fig. 10c) and less in years with deeper water tables such as 2006 (as in Fig. 10f). These increases in $R_{\mathrm{h}}$ were greater than those in NPP when WTD was small, so that lowering the water table reduced NECB during 2002 (as in Fig. 9b). However, these increases in $R_{\mathrm{h}}$ were less than those in NPP when WTD was large so that lowering the water table increased NECB during 2006 (as in Fig. 9d). Increases in $R_{\mathrm{h}}$ were similar to those in NPP during years with intermediate WTD, so that lowering the water table had smaller effects on NECB during the other years of the study. Lowering the water table also decreased $\mathrm{CH}_{4}$ emissions, particularly during 2002 (Table 3).

\section{Discussion}

\subsection{Model processes by which WTD affects $\mathrm{CO}_{2}$ exchange}

The modelling of WTD effects on peatland $\mathrm{CO}_{2}$ exchange in ecosys is based on the explicit coupling of oxidationreduction reactions which drive $\mathrm{C}$ and $\mathrm{N}$ transformations in soil, roots and mycorrhizae with gaseous and aqueous transfers of the substrates and products of these reactions through soil and root profiles with dynamic WTD. This coupling allowed the model to simulate complex responses of $\mathrm{CO}_{2}$ exchange to changes in WTD. The processes by which this simulation was accomplished are described below.

\subsection{1 $\mathrm{CO}_{2}$ effluxes and WTD}

Rates of $\mathrm{C}$ oxidation and hence of $\mathrm{CO}_{2}$ effluxes by microbial, root and mycorrhizal populations in ecosys were governed by their rates of $\mathrm{O}_{2}$ reduction [A14, C14b]. These rates were in turn governed by $\left[\mathrm{O}_{2 \mathrm{~s}}\right][\mathrm{A} 17 \mathrm{a}, \mathrm{b}, \mathrm{C} 14 \mathrm{c}, \mathrm{d}]$ determined by convective and dispersive transport from the atmosphere through gaseous [D16a-d] and aqueous [D19] phases in soil 

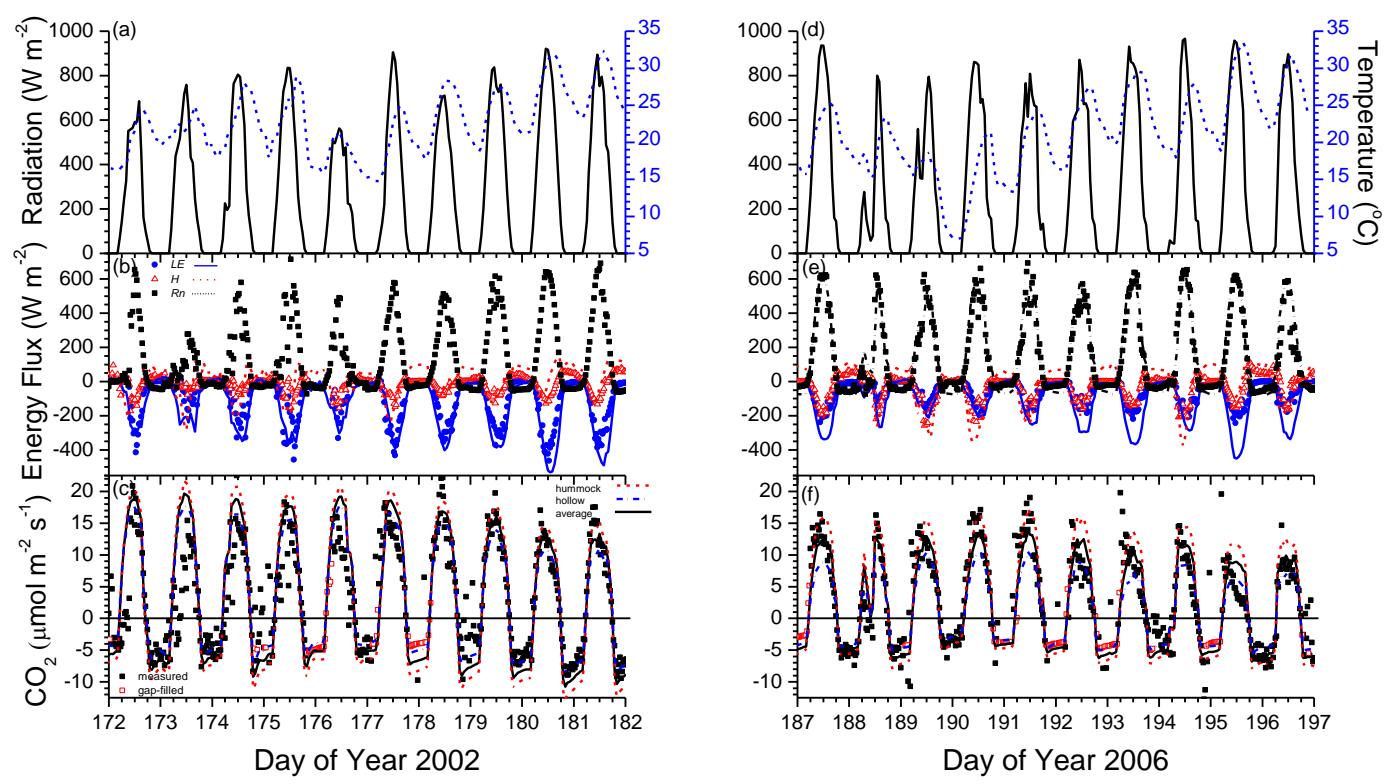

Fig. 5. Radiation and air temperature, energy and $\mathrm{CO}_{2}$ fluxes measured (symbols) and modelled (lines) during warming events with high water table from DOY 173 to 182 in 2002 (0.2 m in Fig. 2) and low water table from DOY 188 to 197 in 2006 (0.7 m in Fig. 2). Positive values represent downward fluxes, negative values represent upward fluxes.

Table 2. Landscape position, mean annual temperature (MAT), total precipitation, average WTD from hummock surface between DOY 120 and 300 (modelled/measured), foliar $\mathrm{N}$ content at anthesis, gross primary productivity (GPP), autotrophic respiration $\left(R_{\mathrm{a}}\right)$, net primary productivity (NPP), heterotrophic respiration $\left(R_{\mathrm{h}}\right)$, methane emissions $\left(\mathrm{CH}_{4}\right)$, export of dissolved organic and inorganic $\mathrm{C}(\mathrm{DOC}+\mathrm{DIC})$, net ecosystem carbon balance $\left(\mathrm{NECB}=\mathrm{NEP}-\mathrm{CH}_{4}-\mathrm{DOC}-\mathrm{DIC}\right)$ and net ecosystem productivity $\left(\mathrm{NEP}=\mathrm{NPP}-R_{\mathrm{h}}\right)$ modelled and derived from eddy covariance (EC) measurements for a boreal fen at Lost Creek, WI. Positive values for NECB and NEP represent $\mathrm{C}$ gains, negative values $\mathrm{C}$ losses. Average values are simple means of those for interconnected hummocks and hollows.

\begin{tabular}{|c|c|c|c|c|c|c|c|c|c|c|c|c|c|}
\hline \multirow[t]{2}{*}{ Year } & \multirow[t]{2}{*}{ Position } & MAT & Precip. & $\begin{array}{l}\text { Water Table } \\
\text { mod./mes. }\end{array}$ & \multirow{2}{*}{$\begin{array}{l}\text { Foliar N } \\
\text { shrub/sedge } \\
\mathrm{g} \mathrm{N} \mathrm{kg} \mathrm{C}^{-1}\end{array}$} & $\begin{array}{l}\text { GPP } \\
\text { shrub/sedge }\end{array}$ & $\begin{array}{l}R_{\mathrm{a}} \\
\text { shrub/sedge }\end{array}$ & $\begin{array}{l}\text { NPP } \\
\text { shrub/sedge }\end{array}$ & $R_{\mathrm{h}}$ & $\mathrm{CH}_{4}$ & $\begin{array}{r}\text { DOC + } \\
\text { DIC }\end{array}$ & NECB & $\begin{array}{r}\text { NEP } \\
\text { mod./EC }\end{array}$ \\
\hline & & ${ }^{\circ} \mathrm{C}$ & $\mathrm{mm} \mathrm{yr}^{-1}$ & $\mathrm{~m}$ & & \multicolumn{8}{|c|}{$\mathrm{gC} \mathrm{m}^{-2} \mathrm{yr}^{-1}$} \\
\hline \multirow[t]{3}{*}{2001} & hummock & & & & $27 / 28$ & $1136 / 171$ & $493 / 080$ & $643 / 091$ & 722 & 2.9 & 0 & 9 & \\
\hline & hollow & & & & $20 / 24$ & $494 / 374$ & $226 / 167$ & $268 / 207$ & 532 & 5.4 & 15 & -77 & \\
\hline & average & 5.6 & 865 & $0.33 / 0.12$ & $23 / 26$ & $815 / 273$ & $360 / 124$ & $456 / 149$ & 627 & 4.2 & 8 & -34 & $-22 /+63$ \\
\hline \multirow[t]{3}{*}{2002} & hummock & & & & $32 / 34$ & $1064 / 153$ & $465 / 074$ & $599 / 079$ & 599 & 3.3 & -2 & 79 & \\
\hline & hollow & & & & $23 / 32$ & $521 / 383$ & $231 / 187$ & $290 / 196$ & 395 & 3.8 & 26 & 61 & \\
\hline & average & 4.9 & 965 & $0.17 / 0.07$ & $28 / 33$ & $793 / 268$ & $348 / 131$ & $445 / 138$ & 497 & 3.6 & 12 & 70 & $+86 /+96$ \\
\hline \multirow[t]{3}{*}{2003} & hummock & & & & $32 / 29$ & $1017 / 146$ & $446 / 063$ & $571 / 083$ & 650 & 1.7 & -1 & 4 & \\
\hline & hollow & & & & $22 / 31$ & $479 / 380$ & $227 / 177$ & $252 / 203$ & 489 & 2.1 & 9 & -45 & \\
\hline & average & 4.1 & 692 & $0.49 / 0.31$ & $27 / 30$ & $748 / 263$ & $337 / 120$ & $411 / 143$ & 570 & 1.9 & 4 & -21 & $-16 /+94$ \\
\hline \multirow[t]{3}{*}{2004} & hummock & & & & $27 / 24$ & $972 / 125$ & $404 / 052$ & $568 / 073$ & 683 & 0.8 & 0 & -43 & \\
\hline & hollow & & & & $21 / 26$ & $482 / 362$ & $207 / 154$ & $275 / 208$ & 520 & 1.1 & 15 & -53 & \\
\hline & average & 4.0 & 814 & $0.32 / 0.35$ & $24 / 25$ & $727 / 244$ & $306 / 103$ & $421 / 141$ & 602 & 1.0 & 8 & -48 & $-40 /+67$ \\
\hline \multirow[t]{3}{*}{2005} & hummock & & & & $31 / 25$ & $1231 / 142$ & $547 / 066$ & $684 / 076$ & 654 & 2.1 & 0 & 103 & \\
\hline & hollow & & & & $22 / 29$ & $554 / 403$ & $251 / 187$ & $303 / 216$ & 497 & 2.8 & 18 & 1 & \\
\hline & average & 5.7 & 790 & $0.30 / 0.35$ & $27 / 27$ & $893 / 273$ & $399 / 127$ & $494 / 146$ & 576 & 2.5 & 9 & 52 & $+64 /+102$ \\
\hline \multirow[t]{3}{*}{2006} & hummock & & & & $30 / 24$ & $1174 / 136$ & $503 / 060$ & $671 / 076$ & 695 & 2.0 & -3 & 52 & \\
\hline & hollow & & & & $22 / 27$ & $587 / 388$ & $263 / 178$ & $324 / 210$ & 525 & 2.1 & 9 & -2 & \\
\hline & average & 6.1 & 665 & $0.60 / 0.49$ & $26 / 26$ & $881 / 262$ & $383 / 119$ & $498 / 143$ & 610 & 2.1 & 3 & 25 & $+31 /+79$ \\
\hline
\end{tabular}

and roots, by dissolution from gaseous to aqueous phases in soil and roots [D14a, b], and by diffusion to and uptake at microbial $[\mathrm{A} 17 \mathrm{a}, \mathrm{b}]$, root and mycorrhizal [C14c, d] surfaces. Above the water table, $\left[\mathrm{O}_{2 \mathrm{~s}}\right]$ calculated from these equations was well above the Michaelis-Menten constant used for microbial, root and mycorrhizal uptake $\left(0.064 \mathrm{~g} \mathrm{O}_{2} \mathrm{~m}^{-3}\right.$ in [A17a] and [C14c]) (Figs. 8, 11), so that $\mathrm{C}$ oxidation was not much limited by $\mathrm{O}_{2}$ reduction. Below the water table, $\left[\mathrm{O}_{2 \mathrm{~s}}\right]$ declined sharply to values that were two orders of magnitude smaller than this constant, so that $\mathrm{C}$ oxidation was strongly limited by $\mathrm{O}_{2}$ reduction. Although $\mathrm{C}$ oxidation in ecosys was also coupled with reduction of DOC by anaerobic heterotrophic fermenters, generating $\mathrm{CO}_{2}, \mathrm{H}_{2}$ and acetate that drives heterotrophic and autotrophic $\mathrm{CH}_{4}$ production 
Table 3. External WTD, mean annual temperature (MAT), total precipitation, average WTD from hummock surface between DOY 120 and 300 , foliar $\mathrm{N}$ content at anthesis, gross primary productivity (GPP), autotrophic respiration $\left(R_{\mathrm{a}}\right)$, net primary productivity (NPP), heterotrophic respiration $\left(R_{\mathrm{h}}\right)$, methane emissions $\left(\mathrm{CH}_{4}\right)$, export of dissolved organic and inorganic $\mathrm{C}$ (DOC $\left.+\mathrm{DIC}\right)$, and net ecosystem carbon balance $\left(\mathrm{NECB}=\mathrm{NEP}-\mathrm{CH}_{4}-\mathrm{DOC}-\mathrm{DIC}\right)$, averaged for hummock and hollow landscape positions, modelled for a boreal fen at Lost Creek, WI. Values at $0.60 \mathrm{~m}$ in bold are the same as those in Table 2.

\begin{tabular}{|c|c|c|c|c|c|c|c|c|c|c|c|c|}
\hline \multirow[t]{2}{*}{ Year } & \multirow{2}{*}{$\begin{array}{l}\text { External } \\
\text { Water } \\
\text { Table } \\
\mathrm{m}\end{array}$} & \multirow{2}{*}{$\begin{array}{l}\text { MAT } \\
{ }^{\circ} \mathrm{C}\end{array}$} & \multirow{2}{*}{$\begin{array}{l}\text { Precip. } \\
\mathrm{mm} \mathrm{yr}^{-1}\end{array}$} & \multirow{2}{*}{$\begin{array}{l}\text { Water Table } \\
\mathrm{m}\end{array}$} & \multirow{2}{*}{$\begin{array}{l}\text { Foliar N } \\
\text { shrub/sedge } \\
\mathrm{g} \mathrm{N} \mathrm{kg} \mathrm{C}^{-1}\end{array}$} & $\begin{array}{l}\text { GPP } \\
\text { shrub/sedge }\end{array}$ & $\begin{array}{l}R_{\mathrm{a}} \\
\text { shrub/sedge }\end{array}$ & $\begin{array}{l}\text { NPP } \\
\text { shrub/sedge }\end{array}$ & $R_{\mathrm{h}}$ & $\mathrm{CH}_{4}$ & $\begin{array}{r}\text { DOC }+ \\
\text { DIC }\end{array}$ & NECB \\
\hline & & & & & & \multicolumn{7}{|c|}{$\mathrm{gC} \mathrm{m}^{-2} \mathrm{yr}^{-1}$} \\
\hline \multirow[t]{3}{*}{2001} & 0.30 & 5.6 & 865 & 0.25 & $22 / 26$ & $762 / 279$ & $338 / 125$ & $424 / 154$ & 580 & 6.8 & 8 & -17 \\
\hline & 0.60 & & & 0.33 & $23 / 26$ & $815 / 273$ & $360 / 124$ & $456 / 149$ & 627 & 4.2 & 8 & -34 \\
\hline & 0.90 & & & 0.45 & $25 / 27$ & $861 / 299$ & $377 / 137$ & $484 / 162$ & 660 & 2.0 & 9 & -25 \\
\hline \multirow[t]{3}{*}{2002} & 0.30 & 4.9 & 965 & 0.14 & $26 / 33$ & $760 / 263$ & $336 / 127$ & $424 / 136$ & 426 & 7.2 & 18 & 109 \\
\hline & 0.60 & & & 0.17 & $28 / 33$ & 793/268 & 348/131 & $445 / 138$ & 497 & 3.6 & 12 & 70 \\
\hline & 0.90 & & & 0.33 & $30 / 35$ & $832 / 295$ & $366 / 142$ & $466 / 153$ & 570 & 1.9 & 12 & 36 \\
\hline \multirow[t]{3}{*}{2003} & 0.30 & 4.1 & 692 & 0.43 & $24 / 29$ & $717 / 252$ & $328 / 119$ & $389 / 133$ & 538 & 4.4 & 7 & -27 \\
\hline & 0.60 & & & 0.49 & 27/30 & $748 / 263$ & $337 / 120$ & $411 / 143$ & 570 & 1.9 & 4 & -21 \\
\hline & 0.90 & & & 0.73 & $30 / 29$ & $822 / 282$ & $359 / 124$ & $463 / 158$ & 591 & 0.6 & 1 & 27 \\
\hline \multirow[t]{3}{*}{2004} & 0.30 & 4.0 & 814 & 0.26 & $22 / 25$ & $690 / 238$ & $297 / 102$ & $393 / 136$ & 557 & 1.3 & 8 & -36 \\
\hline & 0.60 & & & 0.32 & $24 / 25$ & $727 / 244$ & $306 / 103$ & $421 / 141$ & 602 & 1.0 & 8 & -48 \\
\hline & 0.90 & & & 0.36 & $25 / 25$ & $768 / 247$ & $317 / 105$ & $451 / 142$ & 656 & 0.6 & 5 & -68 \\
\hline \multirow[t]{3}{*}{2005} & 0.30 & 5.7 & 790 & 0.21 & $25 / 27$ & $793 / 249$ & $362 / 114$ & $431 / 135$ & 507 & 3.8 & 7 & 48 \\
\hline & 0.60 & & & 0.30 & $27 / 27$ & $893 / 273$ & 399/127 & $494 / 146$ & 576 & 2.5 & 9 & 52 \\
\hline & 0.90 & & & 0.36 & $29 / 27$ & $938 / 276$ & $416 / 129$ & $522 / 147$ & 627 & 1.8 & 8 & 32 \\
\hline \multirow[t]{3}{*}{2006} & 0.30 & 6.1 & 665 & 0.57 & $24 / 25$ & $784 / 257$ & $352 / 121$ & $432 / 136$ & 564 & 2.7 & 1 & 0 \\
\hline & 0.60 & & & 0.60 & $26 / 26$ & $881 / 262$ & $383 / 119$ & $498 / 143$ & 610 & 2.1 & 3 & 25 \\
\hline & 0.90 & & & 0.74 & $29 / 27$ & $925 / 285$ & $396 / 131$ & $529 / 154$ & 620 & 1.6 & 5 & 56 \\
\hline
\end{tabular}

(Grant, 1998) (Tables 2, 3), the energy yield from reduction of DOC was much smaller than that of $\mathrm{O}_{2}$ (Brock and Madigan, 1991), and so drove slower microbial growth [A21] and hence $\mathrm{C}$ oxidation [A13].

Under the site conditions presented to the model in this study, $\left[\mathrm{O}_{2 \mathrm{~s}}\right]$ above the Michaelis-Menten constant to a depth of ca. $0.2 \mathrm{~m}$ (e.g. Fig. $8 \mathrm{~b}$ ) was sufficient to sustain rapid rates of $\mathrm{C}$ oxidation and hence $\mathrm{CO}_{2}$ effluxes (e.g. Fig. 5c). Shallower aerobic zones (e.g. Fig. 8a) reduced $\mathrm{CO}_{2}$ effluxes (e.g. Fig. 3c vs. f), while deeper aerobic zones (e.g. Fig. 8c) increased $\mathrm{CO}_{2}$ effluxes only slightly (Fig. $4 \mathrm{f}$ vs. c). Deeper water tables also raised soil temperatures [D12] (Fig. 10b) by reducing water contents, further contributing to increases in rates of $\mathrm{C}$ oxidation through Arrhenius functions for $R_{\mathrm{h}}$ [A6] and $R_{\mathrm{a}}$ [C22a, b]. These model processes thus enabled the simulation of greater $\mathrm{CO}_{2}$ effluxes over deeper water tables vs. smaller effluxes over shallower, particularly within the upper $0.2 \mathrm{~m}$ of the soil profile, consistent with greater effluxes measured with greater WTD at Lost Creek (Sulman et al., 2009) and elsewhere (e.g. Moore and Dalva, 1993; Moore and Roulet, 1993; Silvola et al., 1996). The model processes were also able to simulate greater $R_{\mathrm{h}}$ and hence greater $\mathrm{CO}_{2}$ effluxes, as well as smaller $\mathrm{CH}_{4}$ effluxes, over greater WTD in hummocks vs. hollows (Figs. 3, 4, 5; Table 2), as has been reported from field sites (Strack and Waddington, 2007).

However, smaller $\mathrm{CO}_{2}$ effluxes were modelled and measured over deeper water tables (Fig. $5 \mathrm{f}$ vs. c) during periods of high temperature (Fig. 5d) and low precipitation (Fig. 2p) when drying, evidenced by higher Bowen ratios (Fig. 6), limited C oxidation in surface soil and litter (Fig. 7c). Drying of surface soil and litter was modelled when capillary rise of water [D7] plus diffusive transfer of vapor [D16] from wetter soil below failed to replace evaporative transfer of vapor to the atmosphere above [D6]. Surface drying therefore depended on soil and hydraulic properties (Fig. 1) as well as on weather. Limitations to $\mathrm{C}$ oxidation caused by drying were modelled from functions for competitive inhibition of heterotrophic decomposers exacerbated by low water content [A3, A5], and for constraints to microbial growth from low water potentials [A15], which together slowed $R_{\mathrm{h}}$ in dry soil and litter (Grant et al., 2012). These limitations were rapidly alleviated by rainfall and consequent surface wetting (Fig. 7), enabling the simulation of $\mathrm{CO}_{2}$ emission pulses commonly observed after rainfall on dry soil (Huxman et al., 2004).

These model processes thus enabled the simulation of smaller $\mathrm{CO}_{2}$ effluxes sometimes measured over deeper water tables. By simulating rises in $\mathrm{CO}_{2}$ effluxes when shallower water tables were lowered (Fig. 10c), and no change or declines in $\mathrm{CO}_{2}$ effluxes when deeper water tables were lowered (Fig. 10f), the model explained apparently contradictory increases, no changes, and decreases of soil respiration that have been observed with increases in WTD (e.g. Lafleur et al., 2005a; Silviola et al., 1996). This model explanation was accomplished without arbitrary parameterizations of aerobic 


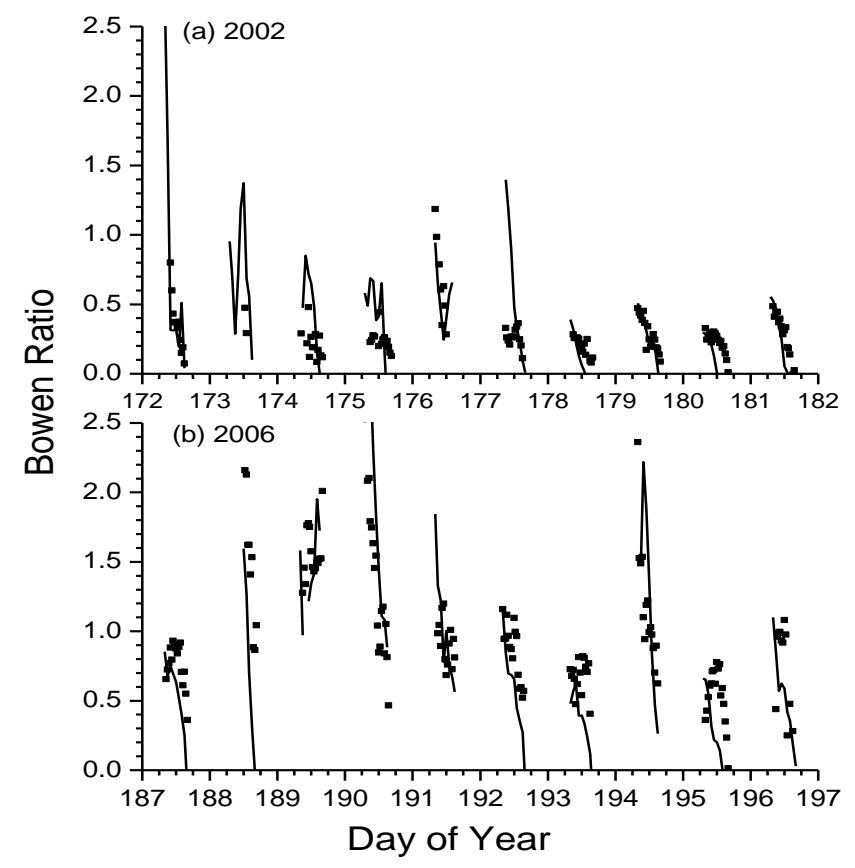

Fig. 6. Bowen Ratios measured (symbols) and modelled (lines) during warming events with high water table from DOY 173 to 182 in 2002 (0.2 m in Fig. 2) and low water table from DOY 188 to 197 in 2006 (0.7 $\mathrm{m}$ in Fig. 2) when net radiation $>250 \mathrm{~W} \mathrm{~m}^{-2}$.

vs. anaerobic respiration used in other wetland models (e.g. Clymo, 1992; St-Hilaire et al., 2010). The complex response to WTD of respiration in ecosys was also demonstrated by Dimitrov et al. (2010a) in an ombrotrophic bog with very different hydrologic characteristics to those of the fen at Lost Creek.

\subsection{2 $\mathrm{CO}_{2}$ influxes and WTD}

The effects of WTD on $\mathrm{CO}_{2}$ influxes were driven in large part by those on $\mathrm{CO}_{2}$ effluxes. Over deeper water tables, increases in $\left[\mathrm{O}_{2 \mathrm{~s}}\right]$ (e.g. Fig. 8a) raised rates of $\mathrm{C}$ oxidation by microbial populations [A13, A14] which drove more rapid microbial growth [A25] and hence nutrient mineralization [A26]. Increases in $\left[\mathrm{O}_{2 \mathrm{~s}}\right]$ also raised rates of $\mathrm{C}$ oxidation by root and mycorrhizal populations [C14a, b], which drove more rapid root and mycorrhizal growth $[\mathrm{C} 20 \mathrm{~b}]$ and hence nutrient uptake [C23]. Greater rates of nutrient uptake increased foliar nutrient contents [C12] (Tables 2 and 3) and hence increased rates of $\mathrm{CO}_{2}$ fixation [C6a, C7, C11]. These greater uptake rates were consistent with the experimental findings of Laiho et al. (2003) that $\mathrm{N}$ uptake by vascular plants was more rapid in drained vs. undrained boreal peatlands. These model processes enabled greater $\mathrm{CO}_{2}$ influxes and hence greater NPP to be simulated over deeper vs. shallower water tables, consistent with greater influxes and NPP measured

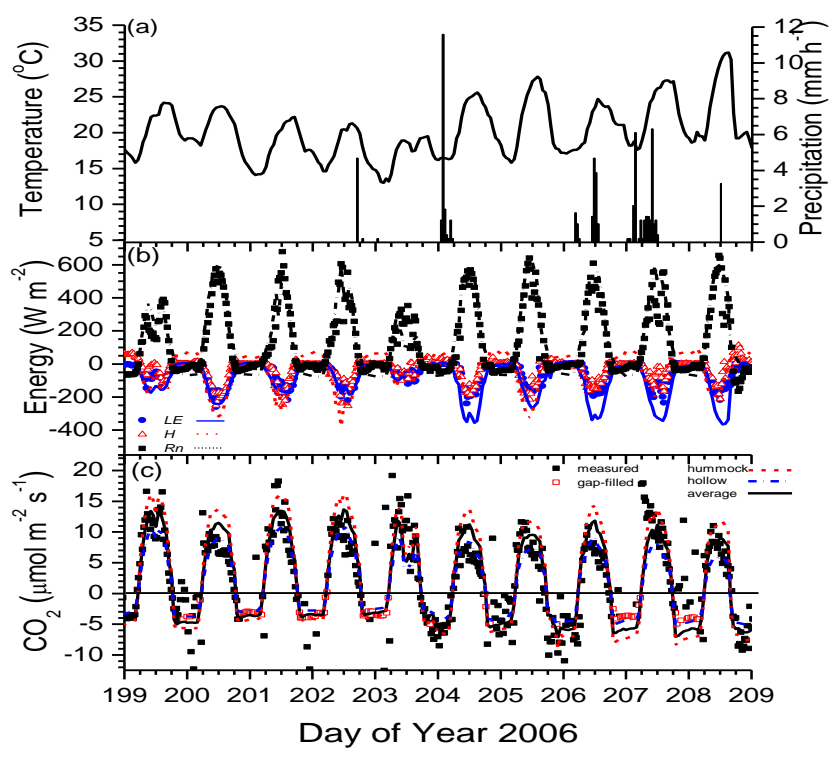

Fig. 7. Air temperature and precipitation, and energy and $\mathrm{CO}_{2}$ fluxes measured (symbols) and modelled (lines) before and after precipitation events with a low water table from DOY 200 to 209 in 2006 (0.7 m in Fig. 2). Positive values represent downward fluxes, negative values represent upward fluxes.

with greater WTD at Lost Creek (Sulman et al., 2009) (e.g. Fig. 3f vs. 3c; Table 2). These processes also enabled the simulation of greater $\mathrm{CO}_{2}$ influxes and hence greater NPP with greater WTD in hummocks vs. hollows (Figs. 3, 4, 5; Table 2), as has been reported from field sites (Strack and Waddington, 2007). This simulation was accomplished without arbitrary parameterizations of productivity under aerobic vs. anaerobic conditions used in other wetland models (e.g. Bond-Lamberty et al., 2007; Sonnentag et al., 2008).

However, smaller $\mathrm{CO}_{2}$ influxes were sometimes modelled and measured over deeper water tables (Fig. $5 f$ vs. c) under high temperature (Fig. 5d) and surface drying (Fig. 6), as was also measured in a boreal peatland by Shurpali et al. (1995). These smaller influxes were modelled from coupled processes for root water uptake [B6] and canopy transpiration [B1] that lowered canopy water potential [B14], conductance [B2] and hence $\mathrm{CO}_{2}$ fixation [C2, C6a, C7] as soil water potentials declined with drying when upward water movement from the saturated soil zone [D7, D16] failed to maintain near-surface water contents (Grant et al., 2012). Similar declines in $\mathrm{CO}_{2}$ influxes measured by EC and modelled by ecosys over greater WTD in an ombrotrophic bog were also attributed by Dimitrov et al. (2011) to water stress in moss caused by near-surface soil drying. Corresponding declines in $\mathrm{CO}_{2}$ influxes have also been measured at WTDs below $0.2-0.5 \mathrm{~m}$ in a boreal fen by Sonnentag et al. (2010). The warm, dry weather and deeper water tables during which 


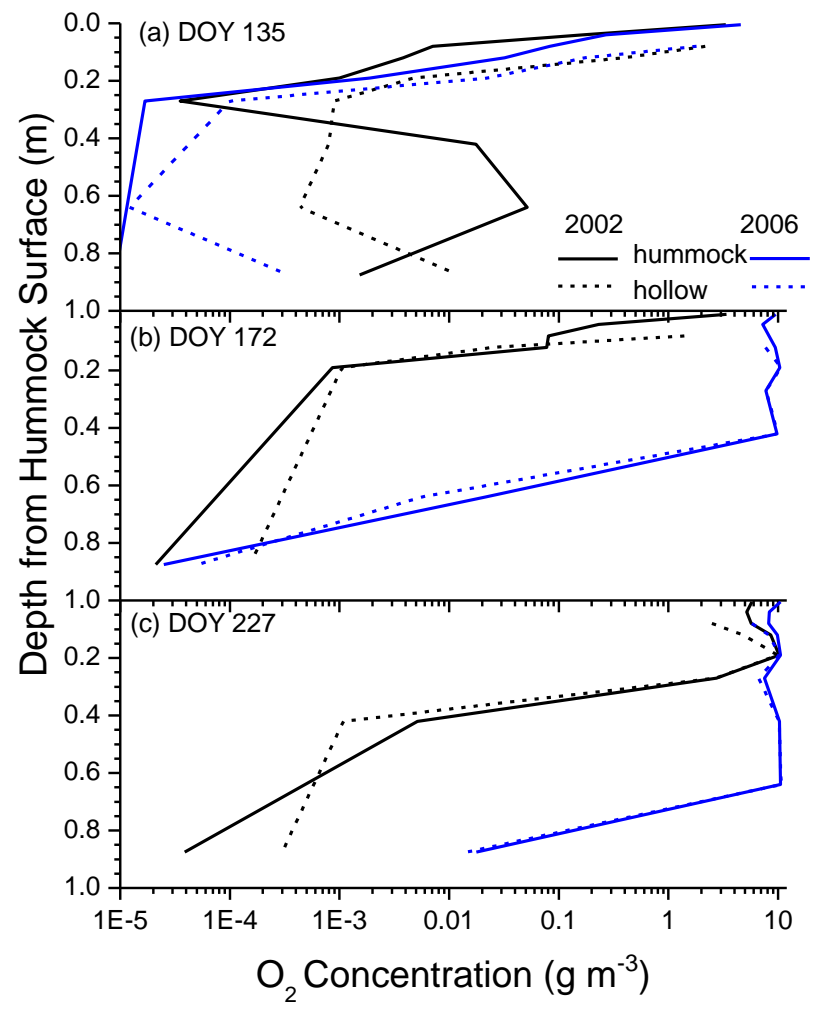

Fig. 8. Vertical profiles of aqueous $\mathrm{O}_{2}$ concentration $\left(\left[\mathrm{O}_{2 \mathrm{~s}}\right]\right)$ modelled below hummocks and hollows on DOY 172 and 227 of 2002 and 2006.
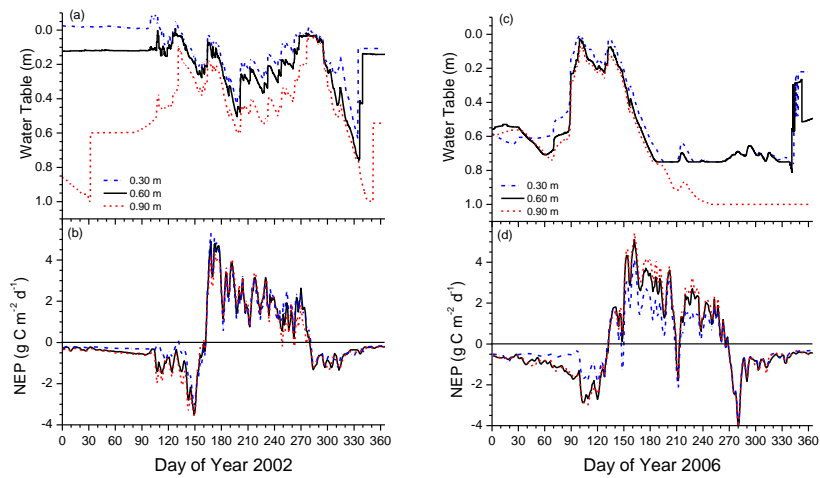

Fig. 9. Changes in water table depth and net ecosystem productivity (NEP) modelled by raising or lowering the depth of the external water table from $0.6 \mathrm{~m}$ (Fig. 1) to $0.3 \mathrm{~m}$ or $0.9 \mathrm{~m}$ in 2002 and 2006. WTD and NEP modelled at $0.6 \mathrm{~m}$ are the same as those in Fig. 2.

these smaller influxes were modelled did not occur frequently enough at Lost Creek to lower annual GPP and NPP, both of which rose with deeper water tables in all years of the study (Tables 2 and 3). However, if warming events over deeper water tables were to occur more frequently under proposed climate change, these adverse effects on annual GPP and NPP might become more apparent.
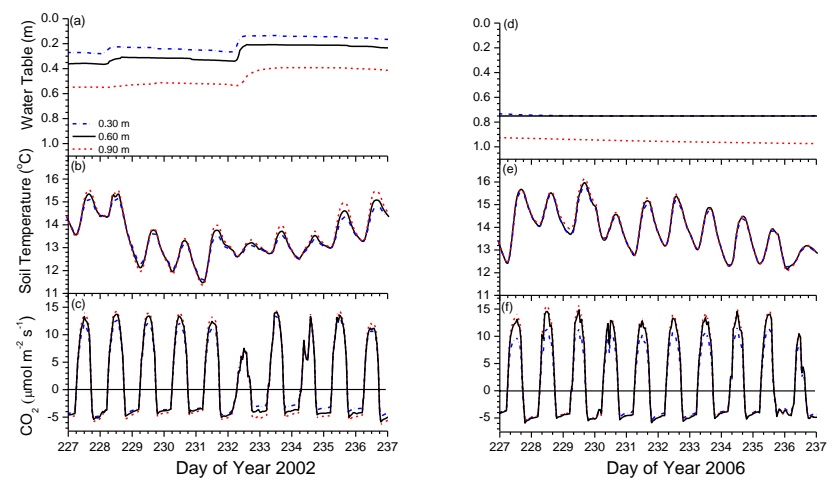

Fig. 10. Changes in water table depth, soil temperatures at $0.12 \mathrm{~m}$, and $\mathrm{CO}_{2}$ fluxes modelled from DOY 228 to 237 in 2002 and 2006 by raising or lowering the depth of the external water table from $0.6 \mathrm{~m}$ (Fig. 1) to $0.3 \mathrm{~m}$ or $0.9 \mathrm{~m}$. $\mathrm{CO}_{2}$ fluxes modelled at $0.6 \mathrm{~m}$ are the same as those in Fig. 4.

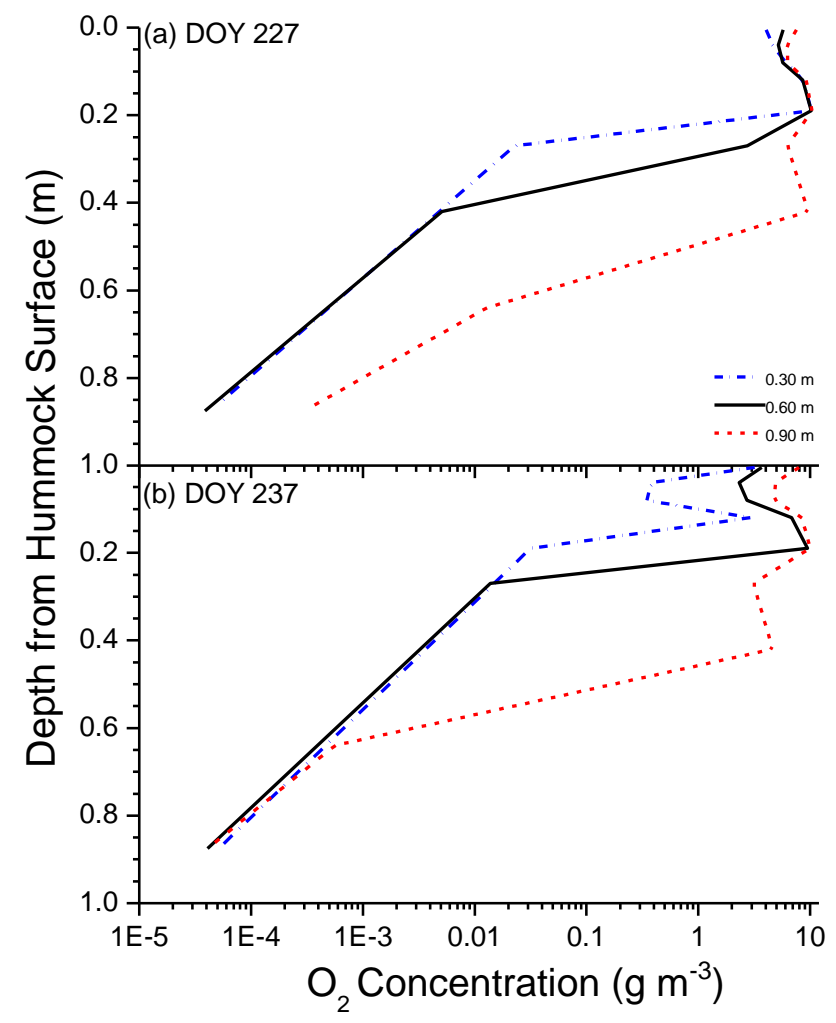

Fig. 11. Vertical profiles of aqueous $\mathrm{O}_{2}$ concentration $\left(\left[\mathrm{O}_{2 \mathrm{~s}}\right]\right)$ modelled below hummocks by raising or lowering the depth of the external water table from $0.6 \mathrm{~m}$ (Fig. 1) to $0.3 \mathrm{~m}$ or $0.9 \mathrm{~m}$ on DOY 227 and 237 in 2002.

\subsubsection{Net $\mathrm{CO}_{2}$ exchange and WTD}

The combined effects of WTD on $\mathrm{CO}_{2}$ effluxes and influxes caused greater NECB to be modelled in a cooler year with shallower water table such as 2002 than in a warmer year with a deeper one such as 2006 (Table 2). However, the 
lowest NECB in this study was modelled in 2004 with an average WTD but the lowest MAT, so that annual NECB was better correlated with MAT than with annual average WTD, as found elsewhere by Lafleur et al. (2005). Sulman et al. (2009) calculated slightly greater NEP in 2002 than in 2006, and lower NEP in 2004, from gap-filled EC fluxes at Lost Creek (Table 2), which was consistent with model results, and so also did not find a correlation between annual WTD and NEP. However, their annual NEP was generally larger than NEP and NECB modelled here, in part because they did not account for losses as $\mathrm{CH}_{4}, \mathrm{DOC}$ and DIC (Table 2), and in part because $\mathrm{CO}_{2}$ effluxes measured by EC during peak emission periods in late spring and early autumn were smaller than those modelled (Fig. 2). In the model, these peaks preceded the phenologically-driven onset of $\mathrm{CO}_{2}$ fixation in spring when $\mathrm{CO}_{2}$ uptake failed to offset $\mathrm{CO}_{2}$ emissions from warming and draining soils, and followed the phenologically-driven termination of $\mathrm{CO}_{2}$ fixation in autumn when $\mathrm{CO}_{2}$ uptake failed to offset $\mathrm{CO}_{2}$ emissions from warmed and drained soils. Similar emission peaks of $2-3 \mathrm{~g} \mathrm{C} \mathrm{m}^{-2} \mathrm{~d}^{-1}$ were measured in a boreal fen by Joiner et al. (1999) during periods between spring thaw and the onset of $\mathrm{CO}_{2}$ fixation, and between the termination of $\mathrm{CO}_{2}$ fixation and autumn freezing. However, the magnitude of these peaks depended on the timing of thawing and freezing vs. that of the onset and termination of $\mathrm{CO}_{2}$ fixation, so that interannual variation in this timing contributed to substantial differences in annual NEP and hence NECB, as modelled in this study (Fig. 2). The comparatively low annual NECB modelled here reflects the growth habit of the shrub - sedge plant functional types at Lost Creek in which there was no long-term accumulation of woody C. Correlations of annual NECB with MAT and WTD among years were complicated by the effects on $R_{\mathrm{h}}$ of changes in litter stocks carried over from previous years with differing productivity.

Differences among annual NECB with WTD in the model were consistent with experimental findings from an open peatland in nearby Minnesota over which a net $\mathrm{C}$ uptake of $32 \mathrm{~g} \mathrm{~m}^{-2}$ was measured from May to October in a wet year and a net $\mathrm{C}$ emission of $71 \mathrm{~g} \mathrm{~m}^{-2}$ was measured during the same period in a dry year (Shurpali et al., 1995). Differences in the model were also consistent with experimental findings from a boreal fen over which a net $\mathrm{C}$ uptake of $92 \mathrm{~g} \mathrm{~m}^{-2}$ was measured in a wetter year and a net $\mathrm{C}$ emission of $31 \mathrm{~g} \mathrm{~m}^{-2}$ was measured during a drier year with earlier snowmelt (Joiner et al., 1999). Contrasting changes in annual NECB modelled when water tables were lowered at smaller vs. greater WTD (e.g. 2002 vs. 2006 in Table 3) were consistent with the findings of Minkkinen et al. (2002) that peat $\mathrm{C}$ accumulation rates usually increase but may decrease with drainage of boreal wetlands in Finland. The contributions of DOC losses to NECB in the model (Tables 2 and 3) were similar to ones of $8-11 \mathrm{~g} \mathrm{C} \mathrm{m}^{-2} \mathrm{y}^{-1}$ or about $17 \%$ of NEP measured in a boreal fen by Strack et al. (2008).

\subsection{Sensitivity of species composition to changes in water table}

Changes in water table had different effects on $\mathrm{CO}_{2}$ exchange by shrubs and sedges in the model. Larger root porosity $\theta_{\text {pr }}[\mathrm{D} 17 \mathrm{~d}]$ used for sedges, as described in Sect. 2.2 above, enabled more rapid $\mathrm{O}_{2}$ uptake through sedge root axes [D16d], particularly when $\left[\mathrm{O}_{2 \mathrm{~s}}\right]$ and hence $\left[\mathrm{O}_{2 \mathrm{r}}\right][\mathrm{D} 14]$ were low. Consequently, $\mathrm{O}_{2}$ uptake $[\mathrm{C} 14 \mathrm{c}]$ and hence $\mathrm{C}$ oxidation [C14b] by sedge roots were less dependent on convectiondispersion [D16a-c] and diffusion [C14d] through soil to root surfaces. Therefore GPP and NPP of sedges increased while those of shrubs decreased in hollows vs. hummocks where the water tables were shallower (Table 2). At the landscape scale, GPP and NPP of sedges declined less than did those of shrubs when water tables were raised (Table 3 ) and root $\mathrm{O}_{2}$ uptake became more dependent on root $\mathrm{O}_{2}$ transport. Conversely, productivity of sedge rose less than that of shrubs when water tables were lowered (Table 3), which was consistent with declines in graminoid biomass and increases in shrub biomass observed after lowering water tables in boreal peatlands from chronosequence studies by Laiho et al. (2003), drainage studies by Weltzin et al. (2003) and natural drying by Sonnentag et al. (2010). Thus, $\theta_{\text {pr }}$ was a key attribute for plant adaptation to wetland conditions in ecosys, allowing changes in species composition with changes in WTD. Such changes in composition are an important adaptive response that reduces the impact of changes in hydrology on wetland productivity. At the present stage of model development, this attribute is not dynamic, although $\theta_{\mathrm{pr}}$ has been found to rise in anoxic soils (Visser et al., 2000).

\section{Conclusions}

The model was able to simulate complex responses of $\mathrm{CO}_{2}$ exchange to changes in WTD at diurnal, seasonal and annual time scales that were consistent with those observed at LC and at similar sites elsewhere. However, these responses required the explicit modelling of key processes, particularly $\mathrm{O}_{2}$ transport, uptake and reduction, by which $\mathrm{CO}_{2}$ exchange is determined in wetlands, and which need to be included in models used to study wetland productivity. At the diurnal time scale the following responses were found:

1. Soil $\mathrm{CO}_{2}$ effluxes rose with greater WTD over shallow water tables (Fig. 4) because increased $\left[\mathrm{O}_{2 s}\right]$ (Fig. 8, 11) hastened microbial and root oxidation-reduction reactions by raising energy yields [A20]. This response required explicit modelling of coupled transport and uptake processes for $\mathrm{O}_{2}$ through soil and roots [A17, C14, D16, D19] which were parameterized independently of the model.

2. Soil $\mathrm{CO}_{2}$ effluxes declined with greater WTD over deeper water tables (Fig. 5) because surface drying 
slowed microbial oxidation-reduction reactions [A3, A5]. This response required modelling of coupled transport [D7] and evaporation [D6] processes for water through soil and surface litter from water potential gradients determined by peat hydrologic properties.

3. Soil $\mathrm{CO}_{2}$ influxes usually rose with greater WTD (Figs. 4,10 ) because more rapid microbial and root oxidationreduction reactions from (1) drove more rapid $\mathrm{N}$ mineralization [A25] and uptake [C23]. This response required modelling a comprehensive set of soil and plant $\mathrm{N}$ transformations fully coupled to those of $\mathrm{C}$.

4. Soil $\mathrm{CO}_{2}$ influxes sometimes declined with greater WTD over deeper water tables during warming events (Fig. 5) because drying soils forced lower canopy water potential [B14] and hence $\mathrm{CO}_{2}$ fixation [C2, C6a, C7]. This response required modelling the effects on $\mathrm{CO}_{2}$ fixation of plant water status solved from hydraulicallydriven water transport along soil-plant-atmosphere water potential gradients [B14].

At the annual time scale, the combined responses (1) to (4) caused

1. NECB to be greater in years with shallow water tables and smaller in years with deeper water tables (Table 2),

2. NECB to decline with increases in WTD in years with shallow water tables and to rise with increases in WTD in years with deeper water tables (Table 3), indicating that deepening water tables may reduce NECB only to a certain depth, below which further deepening may not.

\section{Supplementary material related to this article is available online at: http://www.biogeosciences.net/9/ 4215/2012/bg-9-4215-2012-supplement.pdf.}

Acknowledgements. Field research was funded by DOE BER NICCR 050516Z19 and NSF BIO DEB-0845166. Computational facilities for ecosys were provided by the University of Alberta and by the Compute Canada high performance computing infrastructure.

Edited by: P. Stoy

\section{References}

Adkinson, A. C., Syed, K. H., and Flanagan, L. B.: Contrasting responses of growing season ecosystem $\mathrm{CO} 2$ exchange to variation in temperature and WTD in two peatlands in northern Alberta, Canada, J. Geophys. Res, 116, G01004, doi:10.1029/2010JG001512, 2011.
Blodau, C., Roulet , N. T., Heitmann, T., Stewart, H., Beer, J., Lafleur, P., and Moore, T. R.: Belowground carbon turnover in a temperate ombrotrophic bog, Global Biochemical Cycles, 21, GB1021, doi:10.1029/2005GB002659, 2007.

Boelter, D. H.: Physical properties of peats as related to degree of decomposition. Soil Sci. Soc. Am. Pro., 33, 606-609, 1969.

Bond-Lamberty, B., Gower, S. T., and Ahl, D. E.: Improved simulation of poorly drained forests using Biome-BGC, Tree Physiology, 27, 703-715, 2007.

Brock, T. D. and Madigan, M. T.: Biology of Microorganisms (6th Edn.) Prentice Hall, NJ, 1991.

Clymo, R. S.: Models of peat growth, Suo, 43, 127-36, 1992.

Dang, Q. L. and Lieffers, V. J.: Assessment of patterns of response of tree ring growth of black spruce following peatland drainage, Can. J. For. Res., 19, 924-929, 1989.

Dimitrov, D. D., Grant, R. F., LaFleur, P. M., and Humphreys, E.: Modelling the effects of hydrology on ecosystem respiration at Mer Bleue bog, J. Geophys. Res.-Biogeo., 115, G04043, doi:10.1029/2010JG001312, 2010a.

Dimitrov, D. D., Grant, R. F., LaFleur, P. M., and Humphreys, E.: Modelling subsurface hydrology of Mer Bleue bog, Soil Sci. Soc. Am. J., 74, 680-694, 2010b.

Dimitrov, D. D., Grant, R. F., LaFleur, P. M., and Humphreys, E.: Modelling the effects of hydrology on gross primary productivity and net ecosystem productivity at Mer Bleue bog, J. Geophys. Res.-Biogeo, 116, G04010, doi:10.1029/2010JG001586, 2011.

Flanagan, L. B. and Syed, K. H.: Stimulation of both photosynthesis and respiration in response to warmer and drier conditions in a boreal peatland ecosystem, Global Change Biology, 17, 22712287, doi:10.1111/j.1365-2486.2010.02378.x, 2011.

Frolking, S., Roulet, N. T., Moore, T. R., Lafleur, P. M., Bubier, J. L., and Crill, P. M.: Modelling the seasonal to annual carbon balance of Mer Bleue bog, Ontario, Canada, Global Biogeochem. Cy., 16, doi:10.1029/2001GB001457, 2002.

Grant, R. F.: Simulation of methanogenesis in the mathematical model ecosys, Soil Biol. Biochem., 30, 883-896, 1998.

Grant, R. F.: Simulation of methanotrophy in the mathematical model ecosys, Soil Biol. Biochem., 31, 287-297, 1999.

Grant, R. F.: Modelling topographic effects on net ecosystem productivity of boreal black spruce forests, Tree Physiol., 24, 1-18, 2004.

Grant, R. F. and Roulet, N. T.: Methane efflux form boreal wetlands: theory and testing of the ecosystem model ecosys with chamber and tower flux measurements, Global Biogeochem. Cy., 16, 1054, doi:10.1029/2001GB001702, 2002.

Grant, R. F. and Pattey, E.: Modelling variability in $\mathrm{N}_{2} \mathrm{O}$ emissions from fertilized agricultural fields, Soil Biol. Biochem., 35, 225243, 2003.

Grant, R. F., Oechel, W. C., Ping, C., and Kwon, H.: Carbon balance of coastal arctic tundra under changing climate, Glob. Change Biol., 9, 16-36, 2003.

Grant, R. F., Pattey, E. M., Goddard, T. W., Kryzanowski, L. M., and Puurveen, H.: Modelling the effects of fertilizer application rate on nitrous oxide emissions from agricultural fields, Soil Sci. Soc. Am. J., 70, 235-248, 2006.

Grant, R. F., Barr, A. G., Black, T. A., Margolis, H. A., Dunn, A. L., Metsaranta, J., Wang, S., McCaughey, J. H., and Bourque, C. P.A.: Interannual variation in net ecosystem productivity of Canadian forests as affected by regional weather patterns - a Fluxnet- 
Canada synthesis, Agric. For. Met., 149, 2022-2039, 2009a.

Grant, R. F., Margolis, H. A., Barr, A. G., Black, T. A., Dunn, A. L., Bernier, P. Y., and Bergeron, O.: Changes in net ecosystem productivity of boreal black spruce stands in response to changes in temperature at diurnal and seasonal time scales, Tree Physiol., 29, 1-17, 2009b.

Grant, R. F., Barr, A. G., Black, T. A., Margolis, H. A., McCaughey, J. H., and Trofymow, J. A.: Net ecosystem productivity of temperate and boreal forests after clearcutting - a Fluxnet-Canada synthesis, Tellus B., 62B, 475-496, 2010a.

Grant, R. F., Jassal, R. S., Black, T. A., and Bruemmer, C.: Changes in net $\mathrm{CO}_{2}$ and $\mathrm{N}_{2} \mathrm{O}$ exchange with fertilization of Douglas fir: mathematical modelling in ecosys., J. Geophys. Res., 115, G04009, doi:10.1029/2009JG001094, 2010b.

Grant, R. F., Humphreys, E. R., Lafleur, P. M., and Dimitrov, D. D.: Ecological controls on net ecosystem productivity of a mesic arctic tundra under current and future climates, J. Geophys. Res. Biogeosci., 116, G01031, doi:10.1029/2010JG001555, 2011.

Grant, R. F. Baldocchi, D. D. and Ma, S.: Ecological controls on net ecosystem productivity of a Mediterranean grassland under current and future climates, Agric. For Meteorol., 152, 189-200, 2012.

Huxman, T. E., Snyder, K. A., Tissue, D., Leffler, A. J., Ogle, K., Pockman, W. T., Sandquist, D. R., Potts, D. L., and Schwinning, S.: Precipitation pulses and carbon fluxes in semiarid and arid ecosystems, Oecologia, 141, 254-268, 2004.

Joiner, D. W., Lafleur, P. M., McCaughey, J. H., and Bartlett, P. A.: Interannual variability in carbon dioxide exchanges at a boreal wetland in the BOREAS northern study area, J. Geophys. Res., 104, 27663-27672, 1999.

Krishnan, P., Black, T. A., Barr, A. G., Grant, N. J., Gaumont-Guay, D., and Nesic, Z.: Factors controlling the interannual variability in the carbon balance of a southern boreal black spruce forest, J. Geophys. Res., 113, D09109, doi:10.1029/2007JD008965, 2008.

Lafleur, P. M., Moore, T. R., Roulet, N. T., and Frolking, S.: Ecosystem respiration in a cool temperate bog depends on peat temperature but not on water table, Ecosystems, 8, 619-629, 2005.

Laiho, R., Vasander, H., Penttilä, T., and Laine, J.: Dynamics of plantmediated organic matter and nutrient cycling following water-level drawdown in boreal peatlands, Glob. Biogeochem. Cy., 17, 1053, doi:10.1029/2002GB002015, 2003.

Langergraber, G. and Šimůnek, J.: Modeling variably saturated water flow and multicomponent reactive transport in constructed wetlands, Vadose Zone J., 4, 924-938, 2005

Lieffers, V. J.: Sphagnum and cellulose decomposition in drained and natural areas of an Alberta peatland, Can. J. Soil Sci., 68, 755-761, 1988.

Lieffers, V. J. and Rothwell, R. L.: Effects of drainage on substrate temperature and phenology of some trees and shrubs in an Alberta peatland, Can. J. For. Res., 17, 97-104, 1987.

Lieffers, V. J. and Macdonald, S. E.: Growth and foliar nutrient status of black spruce and tamarack in relation to depth of water table in some Alberta peatlands, Can. J. For. Res., 20, 805-809, 1990.

Macdonald, S. E. and Lieffers, V. J.: Photosynthesis, water relations and foliar nitrogen of Picea mariana and Larix laricina from drained and undrained peatlands, Can. J. For. Res., 20, 995-1000, 1990.
Minkkinen, K., Korhonen, R., Savolainen, I., and Laine, J.: Carbon balance and radiative forcing of Finnish peatlands 1900-2100 The impact of forestry drainage, Glob. Change Biol., 8, 785-799, 2002.

Moore, T. R. and Dalva, M.: The influence of temperature and water-table position on carbon dioxide and methane emissions from laboratory columns of peatland soils, J. Soil Sci., 44, 651664, 1993.

Moore, T. R. and Roulet, N. T.: Methane flux: Water table relations in Northern wetlands, Geophys. Res. Lett., 20, 587-590, 1993.

Muhr, J., Höhle, J., Otieno, D. O., and Borken, W.: Manipulative lowering of the water table during summer does not affect $\mathrm{CO}_{2}$ emissions and uptake in a fen in Germany, Ecol. Appl., 21, 391401, 2011.

Nadelhoffer, K. J., Giblin, A. E., Shaver, G. R., and Laundre, J. A.: Effects of temperature and substrate quality on element mineralization in six arctic soils, Ecology, 72, 242-253, 1991.

Päivänen, J.: Hydraulic conductivity and water retention in peat soils, Acta Forestalia Fennica, 129, 1-70, 1973.

Richardson, A. D., Hollinger, D. Y., Burba, G. G., Davis, K. J., Flanagan, L. B., Katul, G. G., Munger, J. W., Ricciuto, D. M., Stoy, P. C., and Suyker, A. E., Verma, S. B., and Wofsy, S. C.: A multi-site analysis of random error in tower-based measurements of carbon and energy fluxes, Agric. For. Meteorol., 136, 1-18, 2006.

Saxton, K. E., W. J. Rawls, J. S. Romberger, and Papendick, R. I.: Estimating generalized soil-water characteristics from texture, Soil Sci. Soc. Am. J., 50, 1031-1036, 1986.

Scanlon, D., and Moore, T. R.: Carbon dioxide production from peatland soil profiles: the influence of temperature, oxic/anoxic conditions and substrate, Soil Sci., 165, 153-160, 2000.

Shurpali, N. J., Verma, S. B., and Kim, J.: Carbon dioxide exchange in a peatland ecosystem, J. Geophys. Res., 100, 14319-14326, 1995.

Silvola, J., Alm, J., Ahlholm, U., Nykanen, H., Martikainen, P. J.: $\mathrm{CO}_{2}$ fluxes from peat in boreal mires under varying temperature and moisture conditions, J. Ecol., 84, 219-228, 1996.

Sonnentag, O., Chen, J. M., Roulet, N. T., Ju, W., and Govind, A.:, Spatially explicit simulation of peatland hydrology and carbon dioxide exchange: Influence of mesoscale topography, J. Geophys. Res., 113, G02005, doi:10.1029/2007JG000605, 2008.

Sonnentag, O., Kamp, G. V. D., Barr, A. G., and Chen, J. M.: On the relationship between water table depth and water vapor and carbon dioxide fluxes in a minerotrophic fen, Glob. Change Biol., 16, 1762-1776, doi:10.1111/j.1365-2486.2009.02032.x, 2010.

St-Hilaire, F., Wu, J., Roulet, N. T., Frolking, S., Lafleur, P. M., Humphreys, E. R., and Arora, V.: McGill wetland model: evaluation of a peatland carbon simulator developed for global assessments, Biogeosciences, 7, 3517-3530, doi:10.5194/bg-7-35172010, 2010.

Strack, M. and Waddington, J. M.:, Response of peatland carbon dioxide and methane fluxes to a water table drawdown experiment, Global Biogeochem. Cy., 21, GB1007, doi:10.1029/2006GB002715, 2007.

Strack, M., Waddington, J. M., Bourbonniere, R. A., Buckton, E. L., Shaw, K., Whittington, P. and Price, J. S.: Effect of water table drawdown on peatland dissolved organic carbon export and dynamics, Hydrol. Process., 22, 3373-3385, 2008. 
Sulman, B. N., Desai, A. R., Cook, B. D., Saliendra, N., and Mackay, D. S.: Contrasting carbon dioxide fluxes between a drying shrub wetland in Northern Wisconsin, USA, and nearby forests, Biogeosciences, 6, 1115-1126, doi:10.5194/bg-6-11152009, 2009.

Sulman, B. N., Desai, A. R., Saliendra, N. Z., Lafleur, P. M., Flanagan, L. B., Sonnentag, O., Mackay, D. S., Barr, A. G., and Kamp, G. V. D.: $\mathrm{CO}_{2}$ fluxes at northern fens and bogs have opposite responses to inter-annual fluctuations in water table, Geophys. Res. Lett., 37, L19702, doi:10.1029/2010GL044018, 2010.

Sulman, B. N., Desai, A. R., Schroeder, N. M., Ricciuto, D., Barr, A., Richardson, A. D., Flanagan, L. B., Lafleur, P. M., Tian, H., Chen, G., Grant, R. F., Poulter, B., Verbeeck, H., Ciais, P., Peylin, P., Ringeval, B., Baker, I. T., Schaefer, K., Luo, Y., and Weng, E.: Impact of hydrological variations on modeling of peatland $\mathrm{CO}_{2}$ fluxes: results from the North American Carbon Program site synthesis, J. Geophys. Res.-Biogeo., in press, 2012.
Visser, E. J. W., Colmer, T. D., Blom, C. W. P. M., and Voesenek, L. A. C. J.: Changes in growth, porosity, and radial oxygen loss from adventitious roots of selected mono- and dicotyledonous wetland species with contrasting types of aerenchyma, Plant Cell Environ., 23, 1237-1245, 2000.

Weltzin, J. F., Bridgham, S. D., Pastor, J., Chen, J., and Harth, C.: Potential effects of warming and drying on peatland plant community composition, Glob. Change Biol., 9, 141-151, 2003.

Wesely, M. L. and Hart, R. L.:Variability of short term eddycorrelation estimates of mass exchange. in: The forestatmosphere interaction, edited by: Hutchinson, B. A., Hicks, B. B., and Reidel, D., Dordrecht, 591-612, 1985.

Zhang, Y., Li, C., Trettin, C. C., Li, H., and Sun, G.: An integrated model of soil, hydrology, and vegetation for carbon dynamics in wetland ecosystems. Global Biogeochem. Cy., 16, 1061, doi:10.1029/2001GB001838, 2002. 